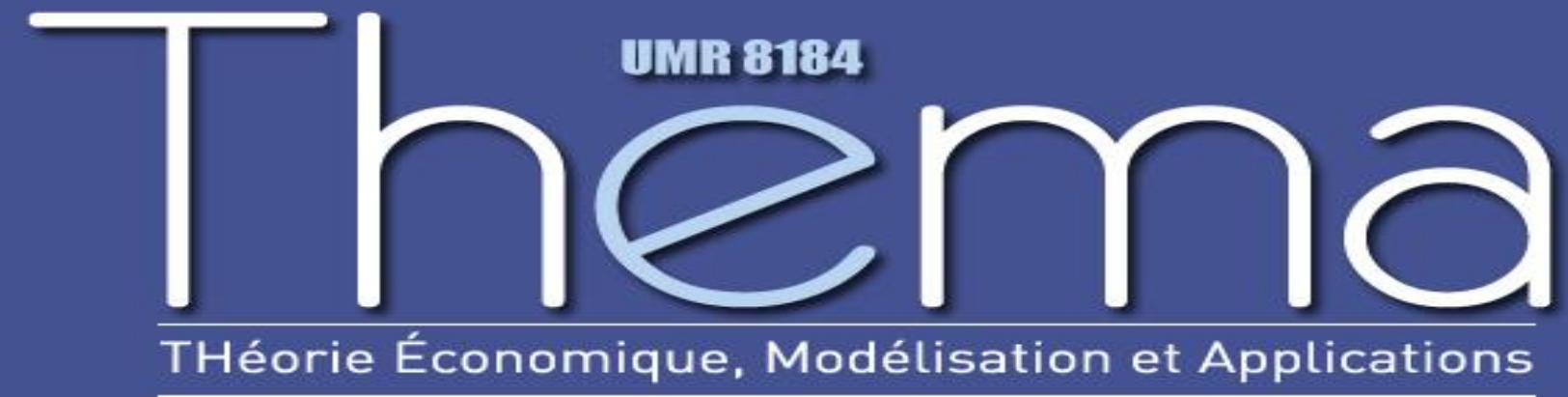

Thema Working Paper $n^{\circ}$ 2013-20

Université de Cergy Pontoise, France

FDI and the labor share in developing countries: A theory and some evidence

Bruno Decreuse

Paul Maarek

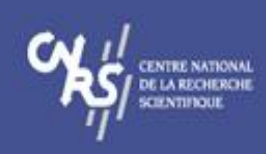

March, 2013 


\title{
FDI and the labor share in developing countries: A theory and some evidence*
}

\author{
Bruno Decreuse ${ }^{\dagger}$ \\ Aix-Marseille School of Economics (Aix-Marseille University) \\ Paul Maarek \\ University of Cergy-Pontoise
}

March 30, 2013

\begin{abstract}
We address the effects of FDI on the labor share in developing countries. Our theory relies on the impacts of FDI on wage and labor productivity in a frictional labor market. FDI have two opposite effects on the labor share: a negative force originated by technological advance, and a positive force due to increased labor market competition between firms. We test this theory on aggregate panel data through fixed effects and IV estimates. We examine the relationship between the labor share in the manufacturing sector and the ratio of FDI stock to GDP. We show that FDI have decreased the labor share in the host countries of our dataset. This impact amounts to between $10 \%$ to $20 \%$ of the mean labor share in our sample.
\end{abstract}

Keywords: FDI; Matching frictions; Firm heterogeneity; Technological advance

J.E.L classification: E25; F16; F21

\footnotetext{
${ }^{*}$ We want to thank a number of colleagues at Aix-Marseille University and at the University of Cergy-Pontoise. We also want to thank two referees and an editor of this review.

†Corresponding author. GREQAM, 2, rue de la charité 13236 Marseille cedex 2, France. Phone number: +33 (0)4 91 1407 22. Fax number: +33 (0) 4911407 27. E-mail: bruno.decreuse@univ-amu.fr
} 


\section{Introduction}

Labor shares - the ratio of labor income to overall income - have plunged in developing countries over the past decades (Harrison [25], Jayadev and Rodriguez [33]). Figure 1 focuses on the aggregate and the manufacturing-sector labor shares. It reports the estimated time effects when we regress labor shares on country fixed effects and time effects. Figure 1 displays strong negative trends: from 1970 to 2000 both series lose about six percentage points. In the manufacturing sector, the bulk of the decline occurs between 1980 and 2000. These changes are contemporaneous of the rise of multinational firms and associated Foreign Direct Investment (FDI). The idea of this paper is to put together these two elements. We argue that the rise in FDI is partly responsible for the fall in labor shares in developing countries.

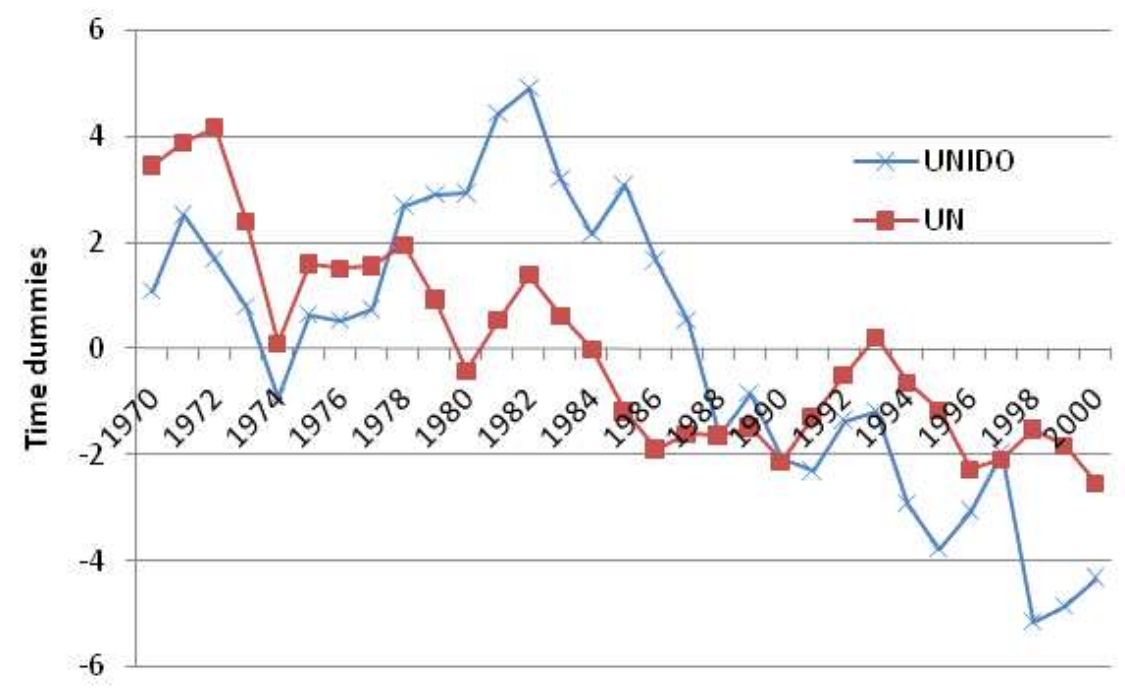

Figure 1: Falling labor shares in developing countries, 1970-2000. We regress the labor share on country fixed effects and time dummies. The list of countries is given in the Appendix. The UN series is the aggregate labor share computed from UN data. The UNIDO series is the labor share in the manufacturing sector. For more details, see Section 3.

Changes in labor shares matter. The LS affects public finance because capital income is typically less taxed than labor income. In France for instance, the effective labor income tax rate is above $40 \%$, whereas the effective capital income tax rate is below $20 \%$. Second, the labor share is strongly linked to income inequality because capital income is much more concentrated than labor income (see Garcia-Penalosa and Orgiazzi [21]). Nonconstant labor shares also cast doubt on the Cobb-Douglas / perfect competition paradigm. Falling labor shares have even more important implications in developing countries. A decrease in labor share originated by FDI inflows may indicate that the overall benefits accruing to globalization are captured by foreign investors, with unchanged standard of living for the population. This is especially true when the host country fails to design the fiscal tools to tax the benefits made by firms financed by foreign capital. FDI-induced falls in labor shares in developing countries also strengthen the protectionist 
view according to which developed economies should not trade with low-wage countries.

There is already a literature arguing that financial globalization reduces the labor share. The theoretical argument follows Rodrik [51] who explains that capital openness appreciates the relative mobility of capital vis-à-vis labor. Harrison [25] has a model in which capital openness increases the statu quo position of firm owners in the bargaining game. This leads to a joint reduction in wage and labor share. To test her idea, Harrison regresses the aggregate labor share on country fixed effects, FDI inflows and outflows, and on a measure of capital controls (among other variables). The idea here is that the magnitude of FDI flows provides a credible threat of capital flight, whereas capital controls reduces capital mobility. Harrison displays mixed evidence in favor of her thesis: inward FDI flows tend to reduce the labor share, whereas capital controls tend to increase it (see also Jayadev [32]). However, significance varies a lot across samples and specifications.

Our paper is devoted to an alternative idea. When a multinational firm enters a developing country, it comes with a better technology and cheaper access to physical capital. Thus it benefits from a large productivity advantage. This foreign firm can easily attract workers by offering a higher wage than its local competitors. Thus wages increase, but in a modest way. In the mean time, output increases a lot more. So far wages increase, but less than value-added. Therefore the labor share falls. However, as competition increases and the productivity advantage declines, wages may increase more rapidly than output and the labor share goes up. In this view, FDI does not hurt labor. Foreign firms pay better wages than local firms. The total number of jobs may also increase with foreign investment. However, that wages increase less than output leads to a fall in the labor share. Noteworthy, this reasoning holds because foreign firms have a large productive advantage. Thus it does not apply to developed economies.

This paper makes two contributions. The main one is theoretical. We provide a search-theoretic model that embodies the previous scenario. The other one is empirical. We provide aggregate evidence in favor of our thesis.

Section 2 proposes a formal theory that relies on the impacts of FDI on wage and labor productivity in a frictional labor market. FDI increases the proportion of high-productivity firms in developing countries ${ }^{1}$. In turn, such a proportion governs the degree of productive heterogeneity: firms are very similar when foreign firms produce no output and when they produce most of output. In a frictional labor market, that foreign firms have a higher productivity offers them market power. The labor share responds to changes in the proportion of foreign firms as a result. The model predicts an inverted Kuznets curve (a U-shaped curve) between the labor share and the proportion of foreign firms. The magnitude of the relationship is governed by the technological gap between foreign and local firms.

We provide three main extensions to the basic model. We start with worker heterogeneity. We assume an extreme form of FDI-skill complementarity: only the skilled workers can occupy foreign jobs. Then FDI have contrasted effects on skilled and unskilled workers. The mean wage of unskilled workers may decrease, whereas their unemployment rate may increase. We then consider there are technological

\footnotetext{
${ }^{1}$ The reason why foreign firms are more productive does not matter. Foreign firms are likely to benefit from advanced technologies. Theoretical models of FDI like Helpman et al [29] also predict that only the most productive firms become multinational companies. Foreign owners self select into high-productivity sectors, and/or where they have a comparative advantage. Finally, foreign-owned firms can borrow at lower cost.
} 
spillovers. The productivity of local firms depends on the proportion of foreign firms. The third extension turns to firms' capital choices. This extension reconciles the competitive model view of the labor share with the arguments we develop here. These different extensions do not affect the U-shaped curve.

In the empirical part of the paper (Section 3), we estimate a reduced-form model on aggregate panel data. We follow Harrison [25] and we regress the labor share on its determinants. We make three departures from Harrison [25]. First, we only consider developing economies. The dataset covers a large panel of countries whose GDP per capita was $60 \%$ or lower than US GDP per capita in 1980 (we change the threshold in robustness checks). Second, the dependent variable is the labor share in the manufacturing sector: the ratio of the total wage bill to GDP produced in this sector. We choose this sector to minimize the measurement problem caused by self-employment, and to abstract from changes in the sectorial composition of output. Third, the variable that captures the magnitude of foreign firms' activity is the stock of inward FDI in percentage of GDP, instead of the flow. The foreign capital stock is a better measure of foreign firms' involvement in the host country than the FDI flow.

We typically explain the labor share by means of FDI stock to GDP, FDI stock to GDP squared, proxy for technological gap, ratio of capital to output, unemployment rate, country fixed effects and time dummies. We focus on fixed effects regressions, but we also discuss outliers, correct for possible endogeneity bias using an IV strategy, and consider alternative measures of globalization as well as time-varying variables describing institutions and education.

To disentangle our mechanism from Rodrik-type arguments, we make the following reasoning. What matters in Rodrik-type arguments is the threat of capital flight. This threat mostly depends on the degree of institutional openness. To some extent, it may also depend on outward FDI, provided that it measures the credibility of the threat. However, it should not depend on inward FDI. That the country attracts foreign firms does not increase local firms' outside options per se. Conversely, that there is an effective entry of FDI is key in our theory. Thus institutional financial openness and outward FDI are associated to Harrison's theory, whereas inward FDI is associated to ours.

Our estimations show that inward FDI stock to GDP depresses the labor shares, whereas institutional financial openness and outward FDI stock to GDP do not count. We find evidence of a U-shaped relationship between the labor share and FDI stock to GDP, but the positive part of the curve is nonrobust to IV estimation. These effects increase with the technological gap, and do not hold in developed economies. The quantitative impact of FDI is substantially large. Consider a country that is characterized by the mean value of FDI stock to GDP and experiences an increase of one standard deviation in this ratio, everything else equal. Fixed effects estimates imply a fall in the labor share that varies between 3.0 to 7.0 points. This impact amounts to between $10 \%$ to $20 \%$ of the mean labor share in our sample. The other determinants of the labor share have the predicted sign: technological gap (-), unemployment rate $(-)$, capital to output ratio $(0 /+)$.

\section{$1.1 \quad$ Literature}

That FDI modifies the factor distribution of output in the host country is ubiquitous in the literature. Most of the papers focus on wage inequality (recent theoretical contributions include Das [10], Liang and Mai [38], and Marjit et al [42]), and display mixed evidence in favor of the thesis according to which FDI 
causes wage inequality, either at industry level ${ }^{2}$ or country level ${ }^{3}$. We complete this strand of literature by focusing on the labor share.

Beyond Harrison [25], recent papers examine the negative effects of globalization on the labor share. Several studies find a negative effect of trade (see, e.g., Ortega and Rodriguez [47], Harrison [25], Guscina [24], and Sylvain [56]). As explained by Ortega and Rodriguez [47], the HOS theory with capital and labor implies that trade should reduce the labor share in developed economies. However, it also implies that trade should increase the labor share in developing countries. Still, Ortega and Rodriguez [47] and Harrison [25] obtain a negative impact of trade in such countries. Our model has nothing to say about trade. However, trade and FDI are correlated. Thus some of our regressions include trade variables to be sure that our results do not simply capture a relationship between LS and trade. The effects of trade variables are sensitive to sample alterations.

In the same line, Diwan [17] and Maarek and Orgiazzi [41] argue that exchange rate crises reduce the labor share. Here again, some of our regressions control for such events. They confirm the negative impact of exchange rate crises.

Rodrik [52] shows that democracies pay higher wages per unit of output. The degree of democracy may be positively correlated with both the labor share and with FDI. Thus we include this variable to avoid another case of omitted variable bias. Ortega and Rodriguez [48] use the same dataset as us and show that the labor share increases with GDP per capita (see also Luo and Zhang [40] on Chinese data). Similarly, our regressions include a proxy for the technological gap, and this variable has a negative effect on the labor share. Our theory predicts such an effect. However, it may also be due to changes in capital intensity along development. This effect remains when we include a proxy for capital intensity.

On the theoretical side, the impact of globalization on firm heterogeneity has been put forward by Melitz [43]. Helpman and Itskhoki [27] introduce matching frictions in the Melitz framework. Firms differ in total factor productivity and trade openness modifies both the share of output produced in each firm and the lowest TFP compatible with participation in international trade. Helpman and Itskhoki [27] study the impacts of globalization on unemployment, whereas Helpman et al [28] focus on wage inequality. This latter model features a U-shaped relationship between wage inequality and the degree of trade integration. The productive side of the theoretical framework is richer than ours: firm continuously differ in total factor productivity and there are price effects induced by trade openness. However, they do not discuss changes in the labor share. The wage is a fixed proportion of output in each firm and so the labor share is constant both at the micro level and at the aggregate level ${ }^{4}$.

\footnotetext{
${ }^{2}$ Feenstra and Hanson [19] on Mexico, Figini and Görg [20] on Ireland and Taylor and Driffield [57] on the UK find a positive effect of FDI on wage inequality, while Blonigen and Slaughter [6] on the US do not find any significant effects.

${ }^{3}$ Gopinath and Chen [23] and Tsai [58] find that FDI has increased wage inequality only in a subset of developing countries, while Basu and Guariglia [2] find a more general relationship. Figini and Görg [20] argue that the positive effect of FDI on wage inequality decreases with development.

${ }^{4}$ There is also another difference with our paper. Helpman et al assume decreasing returns to scale and derive the distribution of firms by fim size; we assume constant returns to scale and the size of individual firms is indeterminate. Helpman et al obtain wage homogeneity within each firm; wage disparity for homogenous labor is the same at the firm level and in the overall economy in our case. The reality is somewhere in the middle. For instance, Abowd et al [1] and subsequent work by Postel-Vinay and Robin [50] use French data and show considerable wage dispersion once controlled for firm and individual effects.
} 
Finally, the growing literature on globalization and labor market imperfections mostly focuses on trade liberalization. A first strand of contributions incorporates matching frictions in two-sector models of international trade (see Davidson and Matusz [13], [14], Davidson et al [12], and Moore and Ranjan [45]). Another strand of contributions uses models of international trade with firm heterogeneity (see Davis and Harrigan [16], Egger and Kreickemeier [18], Helpman and Itskhoki [27]). Davidson et al [15] discuss the outsourcing of high-skill jobs, while Mitra and Ranjan [44] analyze the impact of offshoring in the home economy. A third strand of contributions focuses on multinational activity and labor market imperfections. Most of the existing studies in this literature investigate trade unions as the main source of labor market frictions and focus on partial equilibrium settings (see, e.g., Leahy and Montagna [37]; Lommerud et al [39]). Our paper complements these various papers because we are interested in the labor share rather than in unemployment and/or wage inequality.

\section{The model}

We introduce and solve our model. We also discuss the wage premium paid by foreign firms, the welfare effects of financial openness policies, and capital choices.

\subsection{Basic environment}

The model is static. There are a continuum of workers normalized to one and a continuum of firms of endogenous mass. Workers are homogenous; firms are not: foreign firms differ from local firms.

Each firm, foreign or local, is endowed with a single job slot. Foreign firms are more productive than local firms: the amount of output produced by a foreign and a local firm are respectively $y_{F}$ and $y_{R}$ with $y_{F}>y_{R}$. The productivity differential reflects the technological advance of foreign firms.

Firm entry involves paying a cost that is proportional to expected output. From a national accounting perspective it is important to make explicit the nature of the cost. It can receive two interpretations. On the one hand, it can correspond to the purchase of capital units prior to searching for a worker. On the other hand, it can be due to the regulation that limits the number of firms and guarantees superprofits for the firms managing to enter. Blanchard and Giavazzi [4] consider such shadow costs to ensure that pure profits are not dissipated in entry costs. Capital costs and superprofits are part of value added and do not coincide with labor income. Entry costs cannot correspond to spendings in intermediary goods (that would be subtracted from value added) or to wage payments (that would enter the wage bill).

The cost per unit of output depends on whether the firm is foreign or local. Foreign firms pay $c_{F}$, whereas local firms pay $c_{R}$. Foreign firms face higher costs than local firms, and so $c_{F}>c_{R}$. The entry cost differential $c_{F}-c_{R}$ is due to extra entry difficulties for the foreign firms. Such difficulties may be related to cultural barriers and imperfect financial openness in the host country. Following the interpretation of entry costs as shadow costs of entry, the extra cost is also originated by alternative profit opportunities for the multinationals.

The labor market features matching frictions. Workers and vacancies meet according to the function $M=M(u, n)$. Here $u$ stands for the effective number of job-seekers and $n$ stands for the number of 
vacancies. The meeting technology $M$ is homogenous of degree one to ensure that the unemployment rate does not depend on the number of traders in the economy. It is also strictly increasing in both arguments, strictly concave, and bounded by $\min \{u, n\}$.

Each worker is endowed with two search units - two applications - and so $u=2$. The probability for a worker to receive an offer per search unit is $M(2, n) / 2=m(n)$; it is increasing in $n$. Similarly, $2 m(n) / n$ is the probability of a firm finding a worker; it is decreasing in $n$.

Firms set wages. If a worker receives a unique offer, then s/he is paid the monopsony wage. This monopsony wage is equal to the value of nonmarket opportunities, such as the informal wage. ${ }^{5}$ Without loss of generality the value of nonmarket opportunities is normalized to zero, and so the monopsony wage is zero. ${ }^{6}$ If a worker receives two offers, one from each application, then firms enter Bertrand competition to attach labor services.

The model is static, but it features the main properties of dynamic equilibrium search unemployment models. Accounting for the possibility that the worker receives two offers at a time mimics the case where a worker is already in a job and receives another offer (see, e.g., Postel-Vinay and Robin [50]). As in dynamic models with wage bargaining, the mean wage of our model increases with the vacancy-tounemployed ratio.

\subsection{Labor market equilibrium}

We first consider wage determination. The probability that a worker receives a single job offer is $2 m(n)(1-$ $m(n))$. The wage is then nil and the firm gets the whole output. The probability of receiving two offers is $m(n)^{2}$. The wage then depends on the productivity of both firms. Let $\rho$ denote the proportion of foreign firms. With probability $(1-\rho)^{2}$, the two offers are from local firms and the worker receives output $y_{R}$. With probability $\rho(1-\rho)$, one of the offers comes from a foreign firm and the other comes from a local firm. The worker is then hired by the foreign firm and his wage is $y_{R}$. The firm gets the difference $y_{F}-y_{R}$. With probability $\rho^{2}$, the two offers come from foreign firms. The worker then obtains the marginal product $y_{F}$.

Expected profits for the two types of firms are

$$
\begin{aligned}
& \pi_{F}=-c_{F} y_{F}+\frac{2 m(n)}{n}\left[(1-m(n)) y_{F}+m(n)(1-\rho)\left(y_{F}-y_{R}\right)\right], \\
& \pi_{R}=-c_{R} y_{R}+\frac{2 m(n)}{n}[1-m(n)] y_{R} .
\end{aligned}
$$

Firms enter the economy until profits cover the costs. In equilibrium we have $\pi_{R}=\pi_{F}=0$ and so

$$
\begin{aligned}
& c_{F}=\frac{2 m(n)}{n}\left[1-m(n)+m(n)(1-\rho) \frac{y_{F}-y_{R}}{y_{F}}\right], \\
& c_{R}=\frac{2 m(n)}{n}[1-m(n)] .
\end{aligned}
$$

\footnotetext{
${ }^{5}$ Satchi and Temple [53] and Zenou [62] assume that a worker who does not find a job in the (frictional) formal sector works in the (competitive) unregulated informal sector. In line with this interpretation, the unemployment rate of our model could be considered as the size of the informal sector.

${ }^{6}$ What matters here is that the monopsony wage is lower than the marginal productivity of labor. Thus there is a wedge between the maximum wage firms are willing to pay and the minimum wage that workers are ready to accept. In a dynamic setting, the monopsony wage would be equal to the endogenous reservation wage.
} 
These two equations simultaneously define $\rho$, the proportion of foreign firms, and $n$, the total number of firms. The system can be solved recursively. The free-entry condition (4) for the local firms determines the total number of firms $n$. The free-entry condition (3) then determines the proportion of foreign firms $\rho$. The facts that $c_{F}>c_{R}$ and $y_{F}>y_{R}$ imply that there exists a unique equilibrium with a non-trivial proportion of foreign firms.

The reason why the total number of firms depends only on the effective entry cost faced by local firms is the following. If $c_{F}$ decreases, then profits for foreign firms become positive; new foreign firms enter as result. Since $c_{R}$ remains constant, profit expectations for local firms become negative because they find it more difficult to recruit a worker. The number of local firms goes down until the total number of firms returns to its initial value.

Changes in foreign firms' entry cost $c_{F}$ do not modify the total number of firms; they increase the proportion of foreign firms - applying the implicit function theorem to equations (3) and (4) shows that $d n / d c_{F}=0$ and $d \rho / d c_{F}<0$. An increase in productivity gap $\left(y_{F}-y_{R}\right) / y_{F}$ has similar effects to a fall in foreign firms' entry cost $c_{F}$ : it increases the proportion of foreign firms, but it does not impact the total number of firms.

\subsection{Labor share}

The total wage bill paid by foreign firms is

$$
W_{F}=m(n)^{2} \rho\left[\rho y_{F}+2(1-\rho) y_{R}\right] .
$$

The wage bill corresponds to workers who receive two offers. This event happens with probability $m(n)^{2}$. With probability $\rho^{2}$ the two offers are from foreign firms and the worker receives the totality of output $y_{R}$. With probability $2 \rho(1-\rho)$, one of the two offers is from a local firm and the worker gets $y_{R}$.

The total wage bill paid by local firms is

$$
W_{R}=m(n)^{2}(1-\rho)^{2} y_{R}
$$

Wages correspond to workers who receive two offers from local firms.

Total output in foreign firms is

$$
Y_{F}=m(n) \rho[2-m(n) \rho] y_{F} .
$$

The probability that a worker does not receive a job offer from a foreign firm is $(1-m(n) \rho)^{2}$; the probability that a worker receives an offer from such firms is $1-(1-m(n) \rho)^{2}$. However, the worker may receive two offers from such firms with probability $m(n)^{2} \rho^{2}$. In this case only one of the firms hires him/her. We therefore subtract $m(n)^{2} \rho^{2}$. The result follows.

Total output in local firms is

$$
Y_{R}=m(n)(1-\rho)[2-m(n)(1+\rho)] y_{R} .
$$

The total wage bill is $W=W_{F}+W_{R}$, whereas total output is $Y=Y_{F}+Y_{R}$. We obtain

$$
\mathrm{LS}=\frac{W}{Y}=\frac{m(n)\left[\rho^{2} y_{F}+\left(1-\rho^{2}\right) y_{R}\right]}{\rho[2-m(n) \rho] y_{F}+(1-\rho)[2-m(n)(1+\rho)] y_{R}} .
$$




\subsection{Impact of foreign firms on the labor share}

According to the free-entry conditions (3) and (4), changes in foreign firms' entry costs only lead to changes in the proportion $\rho$ of foreign firms in the total number of firms. To capture the impact of a decrease in foreign firms' entry cost, we only need to differentiate LS given by equation (9) with respect to $\rho$. We obtain:

$$
\begin{aligned}
& \frac{d \mathrm{LS}}{d \rho} \quad \stackrel{\operatorname{sig} n}{=}-d Y / d \rho \times \mathrm{LS}+d W / d \rho \\
& \stackrel{\operatorname{sign}}{=}-(1-\underset{\text { technological gap effect }}{\rho m}(n))\left(y_{F}-y_{R}\right) \mathrm{LS}+\underset{\text { wage competition effect }}{\rho m(n)\left(y_{F}-y_{R}\right)}
\end{aligned}
$$

Two opposite forces are involved:

The technological gap effect tends to decrease the labor share. An increase in the foreign firm proportion raises output because such firms benefit from a high productivity. At given wages, this effect reduces the labor share. The technological gap effect depends on the ability of foreign firms to extract a rent on labor thanks to their better technology.

The wage competition effect tends to increase the labor share. An increase in the proportion of foreign firms raises wage competition between them, which increases wages. At given output, this tends to raise the labor share.

The impact of foreign firms' entry cost on the labor share results from the interplay between these two forces. We have

$$
\frac{d \mathrm{LS}}{d \rho} \stackrel{\text { sign }}{=} \rho^{2} y_{F}-(1-\rho)^{2} y_{R} .
$$

Hence, $d \mathrm{LS} / d \rho$ is non-monotonic in $\rho$. It decreases at first, then reaches a minimum, and finally increases. The technological rent effect initially dominates, whereas it is dominated at a larger proportion of foreign firms. The threshold proportion of foreign firms $\rho^{*}$ below (above) which increased financial openness deteriorates (improves) the labor share results from $d \mathrm{LS} / d \rho=0$. We find $\rho^{*}=\left[1+\left(y_{F} / y_{R}\right)^{1 / 2}\right]^{-1}$.

The pattern of the labor share with respect to the proportion of foreign firms reflects the pattern of productive heterogeneity among firms. The labor share is the same when there are no foreign investors $\left(c_{F}\right.$ sufficiently large, which implies that $\left.\rho=0\right)$ and when output is only produced by foreign firms $\left(c_{R}=c_{F}\right.$, which implies that $\left.\rho=1\right)$. For these two extreme cases, $\mathrm{LS}=m(n) /[2-m(n)]$.

\subsection{Labor share, labor shares, and wages}

The bulk of micro evidence shows that foreign firms pay higher wages than local firms. Our model is in line with this empirical result: the mean wage paid by foreign firms is higher than the one paid by local firms. Moreover, foreign firms may pay higher wages per unit of output than local firms.

The labor shares in foreign and local firms can be computed from equations (5) to (8). We obtain:

$$
\begin{aligned}
\mathrm{LS}_{R} & =\frac{W_{R}}{Y_{R}}=\frac{m(1-\rho)}{2-m(1+\rho)}, \\
\mathrm{LS}_{F} & =\frac{W_{F}}{Y_{F}}=\frac{m}{2-m \rho} \frac{2(1-\rho) y_{R}+\rho y_{F}}{y_{F}} .
\end{aligned}
$$

Average wage paid by type- $i$ firms is $\bar{w}_{i}=\mathrm{LS}_{i} y_{i}, i=R, F$. It follows that

$$
\bar{w}_{F}>\frac{m}{2-m \rho}(2-\rho) y_{R}>\bar{w}_{R} \text {. }
$$


Foreign firms are more productive than local firms; this allows them to attract local workers by paying higher wages.

The labor share may either be higher or lower in foreign firms. Here two effects compete. The first effect is intuitive: foreign firms are more productive, which tends to decrease the labor share at given wage. However, there is also a selection effect. Each time a foreign and a local firm compete to attract a worker, the worker ends up being paid in the foreign firm, whereas the job is destroyed in the local firm.

To understand the selection effect, suppose that the proportion of foreign firms is close to one - that is, $\rho \approx 1$. The labor share in foreign firms is $\operatorname{LS}_{F}=m /(2-m \rho)$; it coincides with the aggregate labor share. The labor share in local firms is $\mathrm{LS}_{R}=0$. The only local jobs are occupied by workers who did not receive another wage offer - the offer would have come from a foreign firm and so the worker would have taken the foreign job. Such workers are paid the monopsony wage and the labor share is minimal in this case.

That the mean wage increases with FDI differs from Rodrik-type arguments. In Harrison [25], financial openness implies that employers can more easily relocate their business in another country. The threat of such a capital flight leads unions to bargain a lower wage. Thus the wage falls at given output. In our model, FDI expands the size of the pie; however, workers may receive a lower share of the pie. When the decline in share dominates the increase in size, then the labor share decreases.

\subsection{Accounting for worker heterogeneity}

In this sub-section, we study the asymmetric impact of FDI on skilled and unskilled workers. Feenstra and Hanson [19] show that the share of wages going to skilled labor increases with FDI entry. We adopt an extreme form of FDI-skill complementarity: only the skilled workers can perform on foreign jobs. This assumption does not change the key relationship between LS and FDI. However, it implies that FDI reduces the well-being of unskilled workers through increased exposure to unemployment and lower wages.

There are $p$ skilled workers and $1-p$ unskilled workers. All workers have two search units. However, skilled workers can occupy foreign jobs, whereas the unskilled cannot. Thus an unskilled worker cannot receive job offers from foreign firms. This reduces the set of potential jobs, and also reduces the scope for Bertrand competition.

The total wage bill paid to skilled workers $W^{S}$ and the total output produced by such workers $Y^{S}$ are very much like the wage bill and output analyzed in the basic model. Thus we have

$$
\begin{aligned}
W^{S} & =p m(n)^{2}\left[\rho^{2} y_{F}+\left(1-\rho^{2}\right) y_{R}\right] \\
Y^{S} & =p \rho m(n)[2-m(n) \rho] y_{F}+p(1-\rho) m(n)[2-m(n)(1+\rho)] y_{R}
\end{aligned}
$$

It follows that the skilled wage-to-output ratio is

$$
\mathrm{LS}^{S}=\frac{m(n)\left[\rho^{2} y_{F}+\left(1-\rho^{2}\right) y_{R}\right]}{\rho[2-m(n) \rho] y_{F}+(1-\rho)[2-m(n)(1+\rho)] y_{R}} .
$$

Thus $\mathrm{LS}^{S}$ is first decreasing and then increasing in the foreign job proportion $\rho$. 
The wage bill paid to unskilled workers $W^{U}$ departs from $W^{S}$. Unskilled workers cannot benefit from meeting foreign firms. Thus each time they meet a local firm and a foreign one, they end up in the local firm and they are paid the monopsony wage. We have

$$
\begin{aligned}
W^{U} & =(1-p) m(n)^{2}(1-\rho)^{2} y_{R}+2(1-p) m(n)(1-m(n))(1-\rho) y_{R} \\
Y^{U} & =(1-p) m(n)^{2}(1-\rho)^{2} y_{R}+2(1-p) m(n)(1-m(n))(1-\rho) y_{R}
\end{aligned}
$$

The unskilled wage-to-output ratio is

$$
\mathrm{LS}^{U}=\frac{m(n)(1-\rho)}{m(n)(1-\rho)+2(1-m(n))} .
$$

It is strictly decreasing in $\rho$. An increase in the foreign firm proportion reduces the set of potential employers for unskilled workers. Not only the odds of employment decrease - the probability of meeting a local employer is reduced -, but also the expected wage goes down - the probability of meeting two local employers falls.

With this extreme form of FDI-skill complementarity, FDI entry reduces the well-being of unskilled workers. Their unemployment risk increases, and their wage expectancies fall. On the contrary, skilled workers always benefit from FDI entry. Consequently, wage and employment inequality expand.

The relative wage of skilled workers increases with the foreign job proportion. However, $\mathrm{LS}^{S}$ is not necessarily larger than $\mathrm{LS}^{U}$. On the one hand, skilled workers have access to more jobs, which increases job competition for their services, thereby raising their wage per unit of output. On the other hand, they may accept a foreign a job while receiving a counter-offer from a local firm. In this case, the wage stays well below output.

We can see this formally. To emphasize the latter mechanism, suppose $y_{R}$ is small compared with $y_{F}$. Then $\mathrm{LS}^{S}$ tends to $m(n) \rho /[2-m(n) \rho]$, whereas $\operatorname{LS}^{U}$ is equal to $m(n)(1-\rho) /[2-m(n) \rho]$. Thus $\mathrm{LS}^{S}<\mathrm{LS}^{U}$ whenever $\rho<1 / 2$.

The overall labor share is $\mathrm{LS}=\left(W^{S}+W^{U}\right) /\left(Y^{S}+Y^{U}\right)$. Thus

$$
\mathrm{LS}=\frac{(1-p) m(1-\rho)^{2} y_{R}+p m\left[\rho^{2} y_{F}+\left(1-\rho^{2}\right) y_{R}\right]}{(1-p) m(1-\rho)[2-(1+\rho) m] y_{R}+p\left[\rho y_{F}(2-m \rho)+(1-\rho)[2-(1+\rho) m] y_{R}\right]}
$$

The overall labor share initially decreases with $\rho$, and finally increases with it. Thus the consideration of worker heterogeneity does not affect the qualitative relationship between FDI and LS.

\subsection{Accounting for technological transfers}

In this sub-section, we introduce technological transfers from foreign to local firms and examine how they alter the relationship between the proportion of foreign firms and the labor share. As far as foreign firms have positive spillover effects on local firms, the technological rent effect tends to decrease with the size of the spillover effect.

We assume that output produced by local firms depends on the proportion $\rho$ of foreign firms, i.e. $y_{R}=y_{R}(\rho)$. The spillover may be either positive - in case of technological transfers - or negative - in 
case foreign firms reduce the ability of local firms to attract local investors, or destroy the network of connections that local firms have ${ }^{7}$.

A positive spillover has a stabilizing effect. An increase in the proportion of foreign firms reduces the technological gap between foreign and local firms. Foreign firms must pay a higher wage as a result, which reduces the incentives to further invest in the country. A negative spillover has a multiplier effect. An increase in the proportion of foreign firms raises the technological gap. Wages go down in foreign firms. This attracts new foreign investors. When this effect is sufficiently strong, there maybe multiple equilibria: equilibria with a large number of foreign firms and low wages, and equilibria with a low number of foreign firms and high wages.

As far as there exists a unique equilibrium, a decrease in entry $\operatorname{cost} c_{F}$ raises the proportion of foreign firms. We can still study the derivative of the labor share with respect to such a proportion:

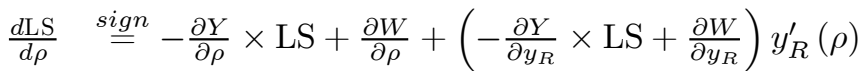

$$
\begin{aligned}
& \stackrel{\text { sign }}{\underline{\underline{y}}}-\left(1-\underset{\text { technological gap effect }}{\rho(n)}\left(y_{F}-y_{R}\right) \mathrm{LS}+\underset{\text { wage competition effect }}{\rho m(n)\left(y_{F}-y_{R}\right)}+(1-\rho) \underset{\text { technological transfer effect }}{\{m(1+\rho)-[2-m(1+\rho)] \mathrm{LS}\}} y_{R}^{\prime}(\rho)\right.
\end{aligned}
$$

As LS $<m(n) /(2-m(n))$, the technological transfer effect has the sign of $y_{R}^{\prime}(\rho)$. The sign as well as the size of the technological transfer effect depends on the sign and magnitude of the spillover. When the spillover is positive, the technological transfer effect tends to reduce the technological gap effect. Conversely, when the spillover effect is negative, the technological transfer effect tends to magnify the technological gap effect.

This extension underlines the need to control for the technological differential between foreign and local firms while trying to assess the relationship between the proportion of foreign firms and the labor share.

\subsection{Accounting for capital choice}

The basic model abstracts from capital choice. In this sub-section, we allow firms to set their capital intensity. We also make the difference between foreign and local firms, which face different capital costs and different total factor productivity. Provided that the elasticity of substitution between capital and labor is lower than one, a decrease in foreign firms' entry cost can raise the labor share by increasing average capital intensity.

Let $k$ denote capital intensity, and assume that output is $a_{i} y(k)$, with $y(0)=0, y^{\prime}(k)>0$, and $y^{\prime \prime}(k)<0$. The elasticity of output with respect to capital intensity is $\alpha(k) \equiv k y^{\prime}(k) / y(k) \in(0,1)$. Total factor productivity parameters and the rental cost of capital are asymmetric. Local firms face the price $r_{R}$, while foreign firms face the price $r_{F} \leq r_{R}$. To simplify, capital investment is made once the worker is recruited.

Capital intensity results from the equality between marginal productivity and marginal cost of capital:

$$
a_{i} y^{\prime}\left(k_{i}\right)=r_{i}, i=F, R
$$

\footnotetext{
${ }^{7}$ See Blomström and Kokko [5] for a survey of the empirical evidence. They conclude that spillovers of foreign technology and skills to local industry is not an automatic consequence of foreign investment. Harrison and McMillan [26] for instance show that foreign firms crowd local firms out of domestic capital market in Ivory Coast.
} 
This implies that foreign firms are more productive than local firms. The labor share is:

$$
\mathrm{LS}=\frac{m(n)\left[\rho^{2}\left(1-\alpha_{F}\right) y_{F}+\left(1-\rho^{2}\right)\left(1-\alpha_{R}\right) y_{R}\right]}{\rho[2-m(n) \rho] y_{F}+(1-\rho)[2-m(n)(1+\rho)] y_{R}}
$$

where $a_{i} y_{i}=y\left(k_{i}\right)$, and $\alpha_{i}=\alpha\left(k_{i}\right), i=F, R$. As $r_{R}=r_{F}$ and $a_{F}=a_{R}=\alpha$, foreign and local firms are no longer different, and the labor share tends to

$$
\mathrm{LS}=(1-\alpha) \frac{m(n)}{2-m(n)}
$$

The labor share is composed of two terms, of which the first is the elasticity of output with respect to labor, and the second accounts for monopsony power derived from search frictions. As $m(n) \rightarrow 1$, the second term tends to one and we are back to the competitive model.

A marginal increase in $\rho$ induced by a marginal decline in $c_{F}$ has the following impacts:

$$
\frac{d \mathrm{LS}}{d \rho} \stackrel{s i g n}{=}-(1-\rho m(n))\left(y_{F}-y_{R}\right) \operatorname{LS}+\rho m(n) \underset{\text { technological gap effect }}{\left[\left(1-\alpha_{F}\right) y_{F}-\left(1-\alpha_{R}\right) y_{R}\right]}
$$

The wage competition effect now depends on the competitive wage differential $\left(1-\alpha_{F}\right) y_{F}-\left(1-\alpha_{R}\right) y_{R}$, rather than on the output differential $y_{F}-y_{R}$. Given that $k_{F}>k_{R}$, we have $\alpha_{R}>\alpha_{F}$ whenever the elasticity of substitution between capital and labor is lower than one. The wage competition effect is magnified when capital and labor are complementary. This point has important implications for the empirical analysis. In the empirical part of the paper (next section), changes in $\rho$ are captured by changes in FDI stock to GDP ratio. This means that changes in $\rho$ and changes in total capital held by foreign firms are observationally equivalent. This may induce a spurious positive impact of FDI stock to GDP ratio on the labor share: an increase in such a ratio may simply raise aggregate capital intensity. It follows that one must control for changes in aggregate capital intensity while trying to find an empirical relationship between the proportion of foreign firms and the labor share. Our regressions include a proxy for capital intensity.

\subsection{From the theory to empirical analysis}

The theoretical model explains the labor share of income as a function of exogenous parameters, among which the degree of financial openness, foreign firms' opportunity cost of entry, and the cost to set up jobs. However, these parameters only affect the labor share because they have an impact on endogenous variables like the vacancy/unemployment ratio or the proportion of jobs in foreign firms. Formally, the labor share as displayed in equation (9) is a function $\operatorname{LS}\left(\rho, m(n), y_{F} / y_{R}\right)$. Thus the broad purpose of our empirical analysis is to estimate the impact of these different variables, with a special focus on the foreign firm proportion.

We estimate a model where we explain the labor share by its potential determinants. We thus define proxies for each of the variables predicted by the model. Most of such variables have a monotonic impact on the labor share. Thus the corresponding proxies enter the regression in a linear way. The foreign firm proportion $\rho$ has a non-monotonic impact. Thus its proxy enters in quadratic way. 
We also add variables that are not predicted by our model, but that other studies emphasize. Omitting them may bias our estimates. We include a set of alternative globalization variables and institutional variables as explained in the Introduction. We especially focus on a de jure measure of financial globalization and on outward FDI.

\section{Empirical analysis}

We use panel data covering developing countries. Fixed effects estimations show that the stock of inward FDI to GDP has a negative impact on the labor share. We also find evidence of a non-monotonic relationship, i.e. decreasing at first, and then increasing. However, the threshold above which the labor share starts increasing with FDI is in the range 150-180\%, and so most of the countries are stuck in the decreasing part of the curve. In addition, the increasing part is non significant when we perform IV estimates. The other determinants of the labor share are in line with the theoretical model, especially the technological gap (-), and unemployment rate (-). Alternative globalization variables are not significant. They do not qualitatively affect the results.

\subsection{Data}

Our theory is about countries where local firms are much less productive than foreign firms. Thus, unlike previous studies, we focus on developing countries. The dataset covers 98 developing countries over the period 1980-2000. We consider all available countries whose GDP per capita was lower than $60 \%$ that of the US in $1980^{8}$. This threshold allows us to consider a large variety of countries, from very poor countries that received very few FDI to high-growth countries that received enormous amounts of FDI. For instance, our sample includes Ireland and Singapore. These countries were far from the technology frontier in 1980. All econometric specifications control for a technological gap that changes over time. We also estimate our empirical model on alternative subsamples: we use different thresholds, and we focus on the complementary subset of developed countries. Our estimates are performed on yearly data to keep the maximum number of observations. The number of observations depends on the number of variables included in the regression. The basic regression with country fixed effects, FDI variables, and a proxy for the technological gap is run over 1203 observations. Adding controls and instrumenting some of the explicative variables reduce the number of observations according to data availability. Data sources and the list of countries are detailed in the Appendix.

The dependent variable is the labor share. Following Daudey [11] and Ortega and Rodriguez [48], we compute it from the UNIDO dataset INDSTAT3. This dataset covers the manufacturing sector. Most other studies consider the aggregate labor share. Thus we now explain our choice. There are two reasons why we use the UNIDO dataset. First, this dataset allows us to abstract from changes in the sectorial composition of output. Globalization causes factor reallocation across sectors. Such factors have different elasticities of output with respect to labor. Thus globalization can affect the labor share for reasons completely exogenous to our theory.

\footnotetext{
${ }^{8}$ If there is no observation in 1980 , we consider the closest year available.
} 
Second, the UNIDO dataset reduces the measurement problems associated with self-employment. The labor share is the ratio of wages to output. Self-employed workers contribute to increase output (the denominator), but they do not report wages (and so the numerator stays fixed). This biases downward the measure of the aggregate labor share. This problem is huge in our case as the proportion of self-employed is much more important in developing countries than in developed countries. To correct this bias, Gollin [22] attributes a fictitious wage to self-employed workers. Fictitious-wage methods involve strong assumptions on the relative productivity of self-employed workers, as well as data on self-employment. Gollin for instance only adjusts the labor share for a single year. Similarly, in some of her regressions, Harrison [25] adjusts the labor share to account for self-employment. She loses two thirds of the observations, and most of the remaining ones are located in developed countries. In the UNIDO dataset, there is a minimum level of activity that eliminates most self-employed and small-family firms from the sample. Thus this dataset does not require the gross wage bill to output ratio to be manipulated. The main drawback of the dataset is that wages do not include employers' contributions, though in our analysis, this may not be a very serious problem because we do not proceed to international comparisons. All our estimates include country fixed effects.

The key explicative variable is the proportion of foreign firms. We use the ratio of (inward) FDI stock to GDP (FDI/Y). This ratio is available from UNCTAD for 200 countries over the period 1980-2005. FDI refers to equity participation over $10 \%$. Such investments indicate that foreign investors play an active role in the management of the firm. These firms benefit from technological advance and have good access to physical capital. Of course, other firms may also benefit from foreign investment. The presumption here is that the percentage of jobs concerned by our analysis is highly correlated with the ratio of FDI stock to GDP. In some of our regressions, we use instead the ratio of FDI stock to total capital stock (FDI/K). This ratio is computed from UNCTAD data on FDI stock and from Klenow and RodriguezClare [35] for the capital stock. We also use data on FDI stocks provided by Lane and Milesi-Ferretti [36]. These data are available over the longer period 1970-2005 and allow us to test the robustness of our results.

There is a potential risk of mismatch between the FDI variable, which is defined for the whole economy, and the labor share variable, which is computed for the manufacturing sector. A substantial proportion of current FDI inflows take place in the service sector. The World Investment report [59] provides summary statistics for the share of FDI stock by sector (classified as primary, secondary, and tertiary sectors) for the period 1988-1999. The share of the secondary sector decreased by $20 \%$ over this period. Meanwhile, the stock of FDI increased by $600 \%$ over the same period. In other words, the change in the sectorial composition is insignificant compared to the overall increase in foreign capital stock. Thus FDI in the manufacturing sector should be highly correlated with FDI for the whole economy.

The theoretical model suggests that the impact of FDI on the labor share depends on the technological gap TG $=\left(y_{F}-y_{R}\right) / y_{F}$ between the host economy and the home-based transnational firm. There are no time-varying statistics for the mean productivity differential $y_{R} / y_{F}$ between local and foreign firms. We use the ratio of local GDP per capita to US GDP per capita, both measured at purchasing power parity. The technological gap variable is measured accordingly by one minus the latter ratio. The idea behind this proxy is that foreign firms are close to the productivity frontier and invest in capital at the lowest 
cost. The US GDP per capita broadly captures both aspects. Of course, the proxy is not perfect: GDP per capita not only depends on total factor productivity and capital intensity, but also on the skill level of the workforce. Average skills are much higher in developed countries than in developing countries and so GDP per capita may overstate the productivity advantage of multinational firms. Some of our regressions include a proxy for the skill level of the workforce, i.e. mean years of schooling. As a robustness check, we also compute the technological gap using a measure of TFP at the country level. TFP is from Klenow [35]. However, TFP understates the productivity differential, because it does not take into account that foreign firms have a cheaper access to physical capital.

The labor share also depends on the matching probability $m(n)$. This probability shapes workers' ability to generate wage competition for their services. This probability is not available as such. However, we use the following property of our model. The probability of staying unemployed coincides with the unemployment rate. It is equal to $\mathrm{UNR}=(1-m(n))^{2}$. We therefore use the unemployment rate as a proxy for (one minus) the matching probability. This variable is available for a limited number of years and countries and is not systematically included in the regressions. One problem with the unemployment rate is that it imperfectly reflects the matching probability in developing economies: are informal workers considered as unemployed? If yes, is it correct to consider them as unmatched? Moreover, this variable can also capture the cyclical component of the labor share (see Pionnier [49]).

We must finally separate the impact of FDI from changes in overall capital intensity in order to capture the specific mechanism through which FDI affects the labor share of income. As argued in section 2.8, foreign firms may have better access to capital markets and FDI entry increases the overall capital intensity of the economy. As emphasized by Bentolila and Saint-Paul [3] and Harrison [25], and as shown in Section 2.8, capital intensity affects the labor share of income if the elasticity of substitution between capital and labor is not equal to one. We consider the ratio of capital stock to output K/Y rather than the ratio of capital stock to labor. The former ratio is governed by changes in the ratio of capital stock to effective units of labor. The UNIDO dataset does not allow us to compute a reliable capital stock series - in many cases the number of observations is clearly insufficient. We follow Henry and Sasson [31] who also work with the UNIDO dataset, and we use investment in the manufacturing sector as a proxy for the capital stock in the same sector. In some regressions we substitute the economywide capital to output ratio to the manufacturing sector investment-to-output ratio.

Some regressions include alternative globalization variables suggested by the literature: a measure of trade openness (OPENT, the usual openness degree - that is the ratio of imports plus exports to GDP), a measure of de jure capital account openness (OPENK) (the composite index constructed by Chinn and Ito [8]), a dummy variable (CRISIS) that takes the value 1 when the nominal exchange rate depreciates by more than $25 \%$, and outward FDI stock. We also consider a set of institutional variables: a dummy variable (DEMO) that takes the value 1 when the political regime is dictatorship and the value 0 when it is a democracy (this variable is from Cheibub and Gandhi [7]), the Regulation of credit, labor and business index (REG) that decreases with the degree of regulation ${ }^{9}$, and an index for the size of Government (SoG) that decreases with Government size. The variables REG and SoG are from the

\footnotetext{
${ }^{9}$ The original index scales $0-10$ and decreases with the degree of regulation. We actually use 10 minus the value of the index.
} 
Fraser Institute.

Table 1 displays descriptive statistics for the core variables. There is substantial variation in the dataset: the standard deviation in the labor share variable accounts for half of the mean value. There is more volatility in the cross-section dimension than in the time dimension. However, the mean standard deviation within country is sufficiently large for panel data analysis.

\section{TABLE 1}

\subsection{Core regressions}

Let $i$ denote the country and $t$ the period. We aim to estimate the following fixed effects model:

$$
\mathrm{LS}_{i t}=a_{i}^{0}+a_{t}^{1}+a^{2} \mathrm{FDI} / \mathrm{Y}_{i t}+a^{3}\left(\mathrm{FDI} / \mathrm{Y}_{i t}\right)^{2}+a^{4} \mathrm{TG}_{i t}+a^{5} \mathrm{UNR}_{i t}+a^{6} \mathrm{~K} / \mathrm{Y}_{i t}+\varepsilon_{i t},
$$

where $a_{i}^{0}$ is the country fixed effect, and $a_{t}^{1}$ is a period dummy. The error term $\varepsilon_{i t}$ is supposed serially uncorrelated. The validation of our model requires that $a^{2}<0, a^{3}>0, a^{4}<0, a^{5}<0$. This statistical model assumes that the different regressors have the same impact in each country. The relationship between FDI/Y and the labor share, for instance, must be the same throughout the sample. This prediction differs somewhat from the theoretical model, whereby the magnitude of the relationship depends on output gap. We also present regressions in which we add the interaction terms FDI/Y $\times$ TG and $(\mathrm{FDI} / \mathrm{Y})^{2} \times \mathrm{TG}$.

Table 2 depicts our main results. Each column is associated with a particular specification. In column a we estimate the relationship without controlling for capital intensity, unemployment rate and time dummies. Column b adds time dummies. Column c includes capital intensity. Column d adds the unemployment rate - and loses half the observations. Columns e and $f$ add the interaction term FDI/Y $\times$ TG. In columns $\mathrm{b}$ to $\mathrm{f}$ regressors are one-period lagged. This allows for potential contemporaneous correlation between the regressors and the error term to be controlled. Squared errors are robust to arbitrary heteroskedasticity between countries.

\section{TABLE 2}

The results can be commented along four dimensions.

First, the labor share is negatively related with FDI/Y. The coefficient associated with FDI/Y is negative, while the coefficient associated with $(\mathrm{FDI} / \mathrm{Y})^{2}$ is positive. The threshold above which an increase in FDI stock to GDP starts increasing the labor share is very high. This threshold can be computed by taking the derivative of the right-hand side of equation (27) with respect to FDI/Y and by setting this derivative to zero. Formally, the threshold $\overline{\mathrm{FDI} / \mathrm{Y}}$ solves $a^{2}+2 a^{3} \overline{\mathrm{FDI} / \mathrm{Y}}=0$. This gives $\overline{\mathrm{FDI} / \mathrm{Y}}=-a^{2} /\left(2 a^{3}\right)$. It varies between $150 \%$ and $180 \%$, which is far above the mean ratio in developing countries.

Second, the quantitative impact of FDI is substantially large. Consider a country characterized by the mean value of FDI/Y (given by Table 1), and suppose it experiences an increase of one standard 
deviation in this ratio, everything else being equal. Estimates in columns a to d imply a fall in the labor share that varies between 3 to 7 points. This impact amounts to between $9 \%$ to $21 \%$ of the mean labor share of our sample.

Third, the other two variables that our model emphasizes have the predicted negative impact. The unemployment rate (UNR) has a strong negative effect on the labor share. The technological gap (TG) also has a negative sign. Consider a country that experiences a decline in technological gap of one standard deviation. The labor share should increase by 1.5 to 5.5 points. Note, however, that most of the studies devoted to the labor share find similar results: different variables correlated with GDP per capita are also correlated with the labor share.

Fourth, Table 2 displays strong interaction effects between FDI/Y and TG. Columns e and $\mathrm{f}$ show that TG loses significance and impact once we add the interaction terms FDI $/ \mathrm{Y} \times \mathrm{TG}$ and $(\mathrm{FDI} / \mathrm{Y})^{2} \times \mathrm{TG}$. The technological gap mainly affects the labor share through magnifying the effects of FDI/Y. This strengthens the view whereby the technological gap variable is more than a simple proxy for time-varying countryspecific features that are correlated with GDP per capita. In addition, the noninteracted variables FDI/Y and $(\mathrm{FDI} / \mathrm{Y})^{2}$ are no longer significant. The magnitude of the relationship between FDI and the labor share is conditional on TG. The higher the technological gap, the larger the impact of foreign firms on the labor share. In other words, if the technological gap equals zero (the interaction term disappears), FDI no longer affects the labor share.

These estimates do not invalidate the magnitude of the effects reported in columns a to d. For instance, consider a country characterized by the mean technological gap and the mean ratio FDI/Y, and assume that this country experiences an increase in FDI/Y of one standard deviation. According to columns e and $\mathrm{f}$, this would reduce the labor share by 7 to 11 points.

\subsection{Robustness checks: outliers}

Figure 2 plots the partial relationship between the labor share and the ratio of FDI stock to GDP. Outliers do not drive the global negative impact of FDI ${ }^{10}$. Figure 2 visually confirms that most of the sample is below the threshold. The flat and increasing parts of the curve are due to a very few countries.

The countries that drive the positive part of the curve are Hong-Kong, Ireland, Macao, and Singapore. These countries have two characteristics over the sample period: impressive growth rates and enormous FDI inflows. These two features are related. High growth rates imply high profit opportunities for foreign investors. In terms of our model, the effective cost of entry $c_{F}$ is very low in these countries, not only because of financial openness $c_{O}$, but also because alternative profits $\bar{\pi}$ are relatively low. Conversely, effective costs of entry are very large in the other countries despite financial openness, because opportunity costs of entry are very high.

In the web Appendix, we run the regressions over various alterations of the initial sample: exclusion of city states, exclusion of extreme observations, using different technological gap thresholds to select countries, and using a different proxy of the technological gap (based on TFP instead of GDP per worker). We also consider several alterations in investment and capital variables: aggregate capital stock

\footnotetext{
${ }^{10}$ Figure 2 shows one obvious outlier: El Salvador in 1997, when the labor share goes from 26 to 81 before going back to 31.
} 


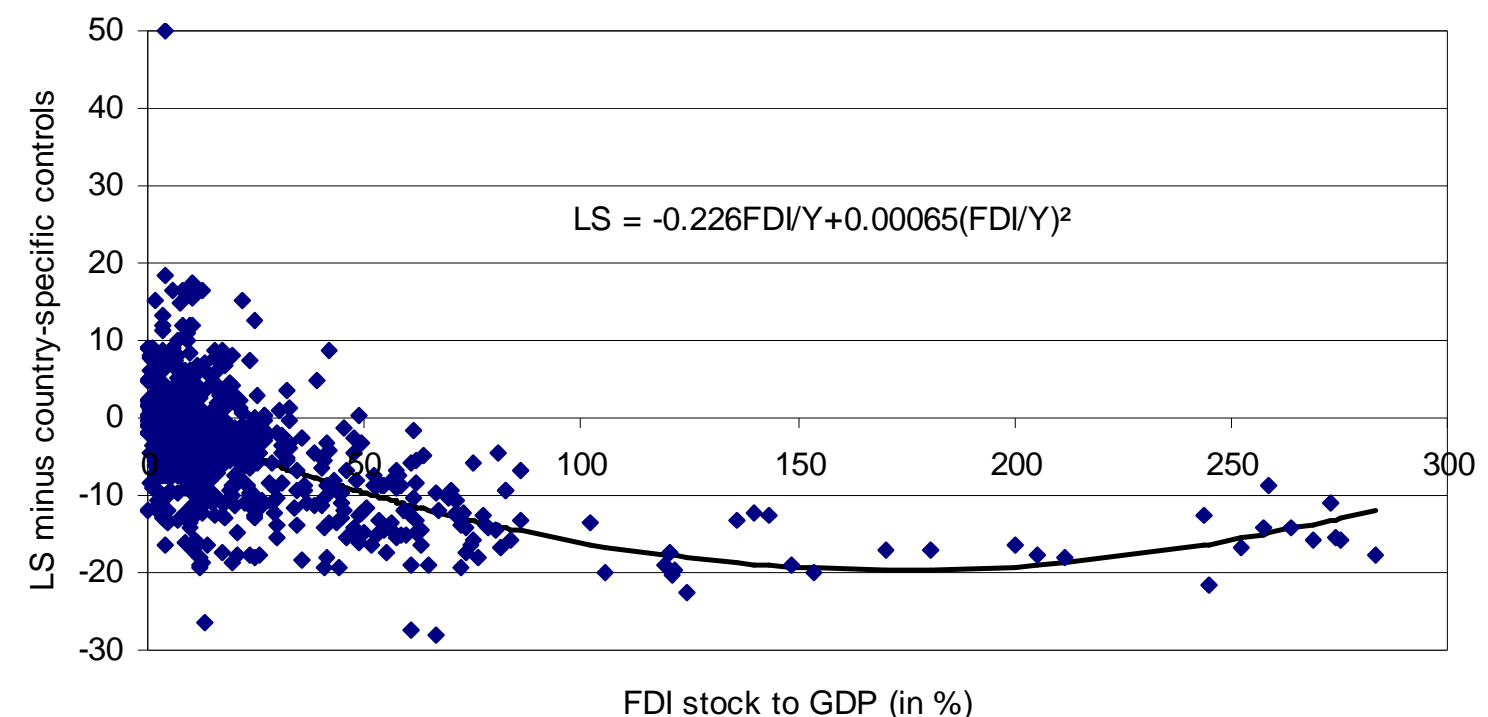

Figure 2: Partial relationship between labor share and FDI stock to GDP. Country-specific controls are TG, I/Y, time effects, and country fixed effects (see Table 2, column c).

vs manufacturing investment, and ratio of FDI stock to capital stock vs ratio of FDI stock to GDP. The results are qualitatively unchanged: all the different parameters have the same sign and significance. There is one exception. As we focus on very poor countries, we fail to identify the increasing part of the relationship. We attribute this result to the small values of the FDI to GDP ratio in such countries. Finally, we run the regressions on different subsets of developed countries. In line with our theory, the FDI variables are not significant.

\subsection{Robustness checks: globalization and institutional variables}

Table 3 considers a large number of globalization and institutional variables. They do not affect the relationship between FDI and the labor share ${ }^{11}$. The Ito and Chinn index of financial openness does not reduce the labor share. Similarly, outward FDI stock tends to increase the labor share, though the effect is not always significant. The magnitude of coefficient, when significant, is similar to our inward FDI stock variable. Nevertheless, mean inward FDI stock is seven times more important than the outward stock in our sample. Thus outward FDI does not offset the negative impact of inward FDI as a result.

Exchange rate crises, measured as a depreciation of $25 \%$ of the currency, has a robust and significant negative impact on the labor share as in Diwan [17] and Maarek and Orgiazzi [41]. Trade does not affect the labor share. The effect is positive, but not significant. This result is at odds with recent empirical evidence suggesting that trade reduces the labor share in developing countries. In the web Appendix, we

\footnotetext{
${ }^{11}$ The FDI/Y coefficient increases across columns. However, column g, which reproduces column-a estimate on column-f sample shows that this effects is mostly due to sample alterations.
} 
consider regressions where we separately include trade and financial openness variables, and we do not include FDI variables. Financial openness does not affect the labor share, whereas trade has a statistically significant negative impact. Once FDI is included, trade loses significance. As shown in the Appendix, this is mostly due to the sample reduction.

The lack of significance of trade and financial openness variables suggests that the largest effects of globalization transit through changes in inward FDI stock. This provides evidence in favor of our theory against Rodrik-type arguments. It is important to realize that we display such evidence for the manufacturing sector in developing countries. Thus we abstract (on purpose) from the effects of globalization on the sectorial composition of output. Moreover our results do not exclude that trade and financial openness may have stronger effects in developed economies.

Bigger Governments, and a less regulated economic environment are associated to higher labor shares. The impact of government size is consistent with Harrison [25], whereas the impact of regulation is consistent with Young and Lawson [61]. The labor share is also higher in democracies (see Rodrik [52]). Finally, the mean schooling years do not affect the labor share.

\section{TABLE 3}

\subsection{Robustness checks: endogeneity concerns}

Despite we consider a large range of globalization and institutional variables, there may be omitted variables that are correlated with both FDI and the labor share. Moreover, the labor share is part of a system of simultaneous equations. To control for simultaneity and omitted variable biases, we develop an IV strategy.

The idea is to find a number of exogenous variables that affect FDI and that should not be determined by the labor share. We consider four instruments, based on the reasons why foreign investors may choose to invest in the host economy. The first two instruments are the number of oppositional seats index (NOS) and the number of seats non aligned/allegiance unknown index (NSNA) from the World Bank database of political institutions. Both instruments are proxies of the political power of the majority. International investors may like to invest in politically stable countries with strong executive power, which have a low probability to experience important changes in political orientations and whose representatives are clearly identified over the political scale. These variables should not be correlated with the labor share as they say nothing about the political orientation of those in power. There are many examples of countries with strong executive power at the right of the political scale as well as at the left.

The third instrument is an index for the existence of independent sub-federal units (ISFU) within the country due to Henisz [30]. Independent sub-federal units can design local policies to attract FDI, and allow foreign investors to negotiate agreements with local authorities. This fiscal competition between local juridictions is only possible if local juridictions have access to a sufficiently large number of policy tools. The fourth instrument is the index of Vanhanen [60] for decentralization of non-agricultural economic resources (DNAER). This composite index measures to what extent the economic system is 
centrally planned, or public-sector dominated, or market oriented with concentrated ownership, or marketoriented with diversified ownership. International investors prefer to produce in countries with competitive market access to economic resources and efficient delocalized bureaucracy.

The main problem is that we try to instrument a quadratic relationship. Moreover, most of the observations are located in the decreasing part of the relationship. To instrument FDIY ${ }^{2}$, we use the square of each variable. As shown below, this procedure is not satisfactory. The excluded instruments are NOS, NSNA, ISFU, DNAER, NOS ${ }^{2}, \mathrm{NSNA}^{2}, \mathrm{DNAER}^{2}$ and included instruments are TG, I/Y, country and time fixed effects and UNR depending on the specification. ISFU ${ }^{2}$ is not included because ISFU is a dummy variable.

Table 4 reports first-stage estimates. Table 5 displays the second-stage estimates and standard test statistics.

TABLE 4

Excluded instruments significantly explain FDI/Y. The sign of the various parameters is economically relevant and highly significant. Conversely, the excluded instruments do not explain well FDI/Y2 ${ }^{2}$ As a result, columns c (without UNR) and d (with UNR) drop FDI/Y2.

Table 5 reports second stage estimates.

\section{TABLE 5}

IV estimates strengthen the negative impact of FDI. The coefficient associated with FDI/Y is about twice the OLS one. The coefficient associated with FDI/Y ${ }^{2}$ is no longer significant. These results are not due to sample alteration when we perform IV regressions. Column $\mathrm{j}$ runs an OLS regression on the same sample as our preferred IV regression. The results are very similar to the basic specification displayed in Table 2

Table 5 reports standard test statistics. We start with tests concerning the first-stage regression. The Cragg and Donald [9] underidentification test in its robust version (Kleibergen and Paap [34]) shows that instruments are well correlated with FDI/Y and the model is identified. By contrast, they are poorly correlated with FDI/ $\mathrm{Y}^{2}$ and the model is unidentified when including such a variable. $\mathrm{F}$ statistics are high, much higher than the value of 10 suggested by Staiger and Stock [54] below which researchers should worry about instrument weakness. Without surprise, the notable exception concerns first-stage estimates for $\mathrm{FDI} / \mathrm{Y}^{2}$.

We now describe tests concerning the second-stage regression. The Stock and Yogo [55] methodology indicates a very low bias of IV relative to OLS estimates. Here again, the regressions that involve FDI/Y2 are much less satisfying. In all cases, the Hansen test fails to reject the null hypothesis of instrument exogeneity. In columns a and b (with and without UNR), we use our four instruments and their squared terms to instrument FDI/Y and FDI/ $\mathrm{Y}^{2}$. FDI/Y is highly significant, whereas FDI/ $\mathrm{Y}^{2}$ is not. In column $\mathrm{c}$ we drop FDI/Y2. Similarly, we drop the squared variables from the first-step regression. Results remain 
highly significant. In columns $\mathrm{d}-\mathrm{g}$ we run regressions for different subsets of instruments. Coefficients remain very similar across regressions, which suggests that the instrument set is valid (see, e.g., Murray $[46])$.

The inclusion of UNR among the regressors leads to a strong reduction in the F statistics. The instruments can still be considered as strong, but this fall in the F statistics must be explained. It may be caused by UNR itself, or by the sample alteration caused by the inclusion of UNR. In column i, we exclude UNR but we perform the estimation on the same sample as in column $\mathrm{h}$. The F statistics is very close to column h. This shows that the fall in the F statistics is only due to the sample alteration.

\section{Conclusion}

Following Rodrik [51], a recent literature argues that financial globalization relatively hurts labor with respect to capital. The scenario is as follows. Financial globalization improves capital mobility. Firm owners use the threat of capital flight when they bargain wages. This decreases the bargained wage and the labor share of income (Harrison [25]). In line with this theory, Harrison [25] reports negative effects of FDI flows and capital account openness. The broad purpose of this paper is to reinterpret these results within another conceptual framework, and to provide more specific evidence in favor of this alternative framework.

We focus on the impacts of FDI on the labor share of income in developing countries. We argue that FDI increases productive heterogeneity between firms in the host country. Foreign firms are more productive and, in a frictional labor market, only need to pay slightly more than local competitors to attract workers. This explains why the labor share falls with FDI. At some point, the magnitude of foreign firms in host activity may become so large that productive heterogeneity starts going down. The labor share would then increase with FDI.

The paper offers a search-theoretic model that allows these two effects to be discussed. Extensions of the model consider additional determinants of the labor share like capital intensity of skilled worker proportion. We then test the main predictions on aggregate data through fixed effects and IV estimations. The dependent variable is the labor share in the manufacturing sector. We show that FDI entry contributed to decrease the labor share by 10 to $20 \%$ of its mean value.

Alternative globalization variables like trade and financial openness have not the same explanatory power on the labor share. This suggests that the largest effects of globalization transit through changes in FDI stock. Importantly, we display such evidence for the manufacturing sector in developing countries. Thus we abstract (on purpose) from the effects of globalization on the sectorial composition of output. Globalization variables may also have different effects in developed economies.

The empirical strategy has limitations. The first one is poor data quality. We deal with developing countries. This means small number of observations and high volatility. The second one is the difficulty to identify a causal relationship. The key problem is the omitted variable bias. The final one relates to our proxies for the different variables. Such proxies are imperfect: they may capture more than the variable they proxy. This leads to an interpretation problem. This calls for further research.

Finally, we point out a negative relationship between productive heterogeneity and the labor share of 
income. This relationship naturally arises in the context of globalization where modern firms can meet technologically obsolete and under-equipped competitors. However, this also happens in times of rapid technological change with emerging industries. We leave this extrapolation of our paper to future work.

\section{References}

[1] J. Abowd, F. Kramarz, D. Margolis, High wage workers and high wage firms, Econometrica 67 (1999) 251-333

[2] P. Basu, A. Guariglia, Foreign direct investment, inequality and growth, J Macroecon 29 (2006) $824-839$

[3] S. Bentolila, G. Saint-Paul, Explaining Movements in the Labor Share, The B.E. Journal of Macroeconomics 0 (2003)

[4] O.J Blanchard, F. Giavazzi, Macroeconomic effects of regulation and deregulation on goods and labor markets, Q J Econ 118 (2003) 879-907

[5] M. Blomström, A. Kokko, The Economics of Foreign Direct Investment Incentives, EIJS Working Paper Series 168, The European Institute of Japanese Studies (2003)

[6] B.A. Blonigen, M.J. Slaughter, Foreign affiliate activity and US skill upgrading, Rev Econ Stat 83 (2001) 362-376

[7] J. Cheibub, J. Gandhi, Classifying Political Regimes: A Sixfold Classification of Democracies and Dictatorships, paper presented at the Annual Meeting of the American Political Science Association (2004)

[8] M. Chinn, H. Ito, A new measure of financial openness, Journal of Comparative Policy Analysis 10 (2008) $307-320$

[9] J. Cragg, S. Donald, Testing Identifiability and Specification in Instrumental Variable Models, Econometric Theory 9 (1993) 222-240

[10] S.P. Das, Gradual globalization and inequality between and within countries, Can J Econ 38 (2005) $852-869$

[11] E. Daudey, The sharing of value-added: data sources, mimeo GREQAM (2005)

[12] C. Davidson, L. Martin, S. Matusz, Trade and search generated unemployment, J Int Econ 48 (1999) 271-299

[13] C. Davidson, S. Matusz, Long-tun lunacy, short-run sanity: a simple model of trade with labor market turnover, Rev Int Econ 14 (2006a) 261-276

[14] C. Davidson, S. Matusz, Trade liberalization and compensation, Int Econ Rev (Philadelphia) 47 (2006b) 723-747 
[15] C. Davidson, S. Matusz, A. Shevchenko, Outsourcing Peter to pay Paul: high skill expectations and low-skill wages with imperfect labor markets, Macroecon Dynam 12 (2008) 463-479

[16] D. Davis, J. Harrigan, Good jobs, bad jobs and trade liberalization, J Int Econ 84 (2011) 26-36

[17] I. Diwan, The labor share during financial crises: new results, unpublished (2002)

[18] H. Egger, U. Kreickemeier, U., Firm heterogeneity and the labour market effects of trade liberalization, Int Econ Rev (Philadelphia) 50 (2009) 187-216

[19] R.C. Feenstra, G.H. Hanson, Foreign Direct Investment and relative wages: evidence from Mexico's maquiladoras, J Int Econ 42 (1997) 371-393

[20] P. Figini, H. Görg, Does Foreign Direct Investment affect wage inequality? An empirical investigation, World Econ 34 (2011) 1455-1475

[21] C. Garcia Peñalosa, E. Orgiazzi, GINI DP 12: Factor Components of Inequality. A Cross-Country Study, GINI Discussion Papers 12, AIAS, Amsterdam Institute for Advanced Labour Studies (2011)

[22] D. Gollin, Getting income shares right, J Polit Econ 110 (2001) 458-475

[23] M. Gopinath, W. Chen, Foreign Direct Investment and wages: a cross-country analysis, J Int Trade Econ Dev 12 (2003) 285-309

[24] A. Guscina, Effects of Globalization on Labor's Share in National Income, IMF working paper 06/294 (2006)

[25] A.E. Harrison, Has Globalization Eroded Labor's Share? Some Cross-Country Evidence, MPRA Paper 39649, University Library of Munich, Germany. (2005)

[26] A. Harrison, M. McMillan, Does direct foreign investment affect domestic credit constraints?, J Int Econ 61 (2003) 73-100

[27] E. Helpman, O. Itskhoki, Labor market rigidities, trade and unemployment, Rev Econ Stud 77 (2010) 1100-1137.

[28] E. Helpman, O. Itskhoki, S. Redding, Inequality and unemployment in a global economy, Econometrica 78 (2010) 1239-1283

[29] E. Helpman, M.J. Melitz, S.R. Yeaple, Export vs FDI with heterogenous firms, Am Econ Rev 94 (2004) 300-316

[30] W.J. Henisz, The Institutional Environment for Infrastructure Investment. Industrial and Corporate Change, 11 (2002) 355-389

[31] P. Henry, D. Sasson, Capital market integration and wages, NBER Working Paper No 15204 (2009)

[32] A. Jayadev, Capital account openness and the labour share of income. Cambridge Journal of Economics, 31 (2007) 423-443 
[33] A. Jayadev, F. Rodriguez, The Declining Labor Share of Income. Human Development Research Paper No 2010-36, Human Development Report Office, United Nations Development Programme (2010)

[34] F. Kleibergen, R. Paap, Generalized reduced rank tests using the singular value decomposition, Journal of Econometrics 133 (2006) 97-126

[35] P.J. Klenow, A. Rodriguez-Clare, Externalities and growth, in: P. Aghion, S. Durlauf (Eds), Handbook of Economic Growth vol. 1A, Chapter 11, Elsevier, (2005), 817-861

[36] P.R. Lane, G.M. Milesi-Ferretti, The external wealth of nations mark II: revised and extended estimates of foreign assets and liabilities, J Int Econ 73 (2007) 223-250

[37] D. Leahy, C. Montagna, Unionisation and Foreign Direct Investment: challenging conventional wisdom?, Econ J 110 (2000) C80-C92

[38] W.-J. Liang, C.-C. Mai, Capital flows, vertical multinationals, wage inequality, and welfare, Rev Devel Econ 7 (2003) 599-603

[39] K.E. Lommerud, F. Meland, L. Sørgard, Unionised oligopoly, trade liberalization and location choice, Econ J 113 (2003) 782-800

[40] C. Luo, J. Zhang, Declining Labor Share: Is China's Case Different?, China \& the world economy 18 (2010) $1-18$

[41] P. Maarek, E. Orgiazzi, Currency crises and the labor share, Economica (forthcoming)

[42] S. Marjit, H. Beladi, A. Chakrabarti, Trade and wage inequality in developing countries, Econ Inq $42(2004) 295-303$

[43] M. Melitz, The Impact of Trade on Intra-Industry Reallocations and Aggregate Industry Productivity. Econometrica 71 (2003) 1695-1725

[44] D. Mitra, P. Ranjan, Offshoring and unemployment: The role of search frictions labor mobility? J Int Econ 81 (2010) 219-229

[45] M.P. Moore, P. Ranjan, Globalisation vs skill-biased technological change: implications for unemployment and wage inequality, Econ J 115 (2005) 391-422

[46] M. Murray, Avoiding Invalid Instruments and Coping with Weak Instruments, Journal of Economic Perspectives 20 (2006) 111-132.

[47] D. Ortega, F. Rodriguez, Openness and factor shares, Unpublished (2002).

[48] D. Ortega, F. Rodriguez, Are capital shares higher in poor countries? Evidence from industrial surveys, Wesleyan Economics Working Paper No 2006-023 (2006)

[49] P.A. Pionnier, Le partage de la valeur ajoutée en France, 1949-2008: aspects méthodologiques, Economie et Prévision 402 (2009) 
[50] F. Postel-Vinay, J.-M. Robin, Wage dispersion with worker and employer heterogeneity, Econometrica 70 (2002) 2295-2350

[51] D. Rodrik, Has globalization gone too far? Institute for International Economics, Washington, (1997)

[52] D. Rodrik, 1999, Democracies Pay Higher Wages, Q J Econ 64 (1999) 707-738

[53] M. Satchi, J. Temple, Labor Markets and Productivity in Developing Countries, Review of Economic Dynamics, 12 (2009) 183-204

[54] D. Staiger, J. Stock, Instrumental Variables Regression with Weak Instruments, Econometrica 65 (1997) 557-586

[55] J.H. Stock, M. Yogo, Testing for Weak Instruments in Linear IV Regression. In "Identification and Inference for Econometric Models: Essays in Honor of Thomas Rothenberg, ed. D.W. Andrews and J.H. Stock, 80-108. Cambridge University Press (2005)

[56] A. Sylvain, Part des salaires et mondialisation: une analyse économétrique pour treize pays de l'OCDE, 1970-2002, Economie Internationale 114 (2007) 93-132

[57] K. Taylor, N.L. Driffield, Wage inequality and the role of multinationals: evidence from UK panel data, Labour Econ 12 (2005) 223-249

[58] P.-L. Tsai, Foreign Direct Investment and income inequality: further evidence, World Dev 23 (1995) $469-483$

[59] United Nation, World Investment Report: Transnational Corporations, Extractive Industries and Development (2007)

[60] T. Vanhanen, Democratization: A Comparative Analysis of 170 Countries. London: Routledge (2003)

[61] A. Young, R. Lawson, Capitalism and Labor Shares: A Cross-Country Panel Study, 1970 to 2010, Available at SSRN: http://ssrn.com/abstract=2205786 or http://dx.doi.org/10.2139/ssrn.2205786 (2013)

[62] Y. Zenou, Job search and mobility in developing countries. Theory and policy implications, Journal of Development Economics 86 (2008) 336-355 


\section{APPENDIX}

- CRISIS: Exchange rate crisis. Dummy equal to one if the percentage increase in nominal exchange rate is larger than $25 \%$. The exchange rate is measured at the end of the year.

Source: IMF

- DEMO: Type of regime. Coded 0 if democracy; 1 if dictatorship

Source: Cheibub and Gandhi (2004)

- DNAR: Decentralization of non-agricultural ressources. each country's economic system was categorized as being centrally planned, public sector dominated, market oriented with concentrated ownership, or market oriented with diversified ownership; then the degree of concentration of ownership within each category was determined.

Source: Vanhanen (2003)

- EDU: Average schooling years in the total population aged 25 and over.

Source: Barro and Lee (2000)

- FDI/Y = Ratio of Foreign Direct Investment stock to GDP

Source: UNCTAD and Lane and Milesi-Ferretti (2007) for FDI

Data available at http://www.imf.org/external/pubs/ft/wp/2006/data/wp0669.zip

- FDI/Y_out = Ratio of Foreign Direct Investment asset stock to GDP

Source: UNCTAD and Lane and Milesi-Ferretti (2007) for FDI

- FDI/K = Ratio of Foreign Direct Investment stock to total capital stock

Source: UNCTAD and Lane and Milesi-Ferretti (2007) for FDI

Data available at http://www.imf.org/external/pubs/ft/wp/2006/data/wp0669.zip

Source: Klenow and Rodriguez-Clare (2005) for the capital stock

- $\mathrm{I} / \mathrm{Y}=$ Ratio of Investment to value-added in the manufacturing sector

Source: UNIDO industrial statistics database INDSTAT3 2005 ISIC Rev.2

Values lower than 0 have been omitted from the sample

- ISFU: Independent Sub-Federal Units. Coded 0 if no ISFU; 1 if ISFU

Source: The Political Constraints Index, Henisz (2004)

- $\mathrm{K} / \mathrm{Y}=$ Ratio of total capital stock to total GDP

Source: Klenow and Rodriguez-Clare (2005)

- LS: Labor share $=$ Ratio of wages and salaries to value added $(\times 100)$

Source: UNIDO industrial statistics database INDSTAT3 2005 ISIC Rev.2 
- NOS: Number of Oppositional Seats. It is the number of seats in the legislature of all the parties in opposition.

Source: World Bank database of Political Institutions (2005)

- NSNA: Number of Seats non-aligned/allegiance unknown. This corresponds to the number of seats in the legislature that are not always aligned on government positions.

Source: Database of Political Institutions (2005). World Bank.

- OPENK: Chinn and Ito financial openness index. Composite index varying between 2.62 (very open) and -1.75 (close). It is based on four dummy variables reflecting the four major categories on the restrictions on external accounts: presence of multiple exchange rates, restrictions on current account transactions, restrictions on capital account transactions, requirement of the surrender of export proceed.

Source: Chinn and Ito (2007)

Data available at http://www.ssc.wisc.edu/〜mchinn/kaopen_2006.xls

- OPENT $=$ Ratio of total exports and imports to GDP

Source: World bank. World Development Indicators 2005

- REG: 10 minus the Regulation of Credit, Labor and Business. The index ranges from 0 to 10 where 0 corresponds to low regulation and 10 corresponds to high regulation.

Source: Fraser Institute

- SoG: Size of Government: Expenditures, Taxes, and Enterprises. The index ranges from 0-10 where 0 corresponds to large government and 10 to low government.

Source: Fraser Institute

- TG: Technological gap = One - percentage gap between local GDP (PPP) per capita and US GDP per capita $(\times 100)$

Source: World bank. World Development Indicators 2005

- UNR: Unemployment rate = Ratio of unemployed workers to total labor force

Source: World bank. World Development Indicators 2005

- List of the developing countries (TG > 40\%): Algeria, Argentina, Bangladesh, Barbados, Belize, Bolivia, Botswana, Brazil, Bulgaria, Burkina-Faso, Burundi, Cameroon, Central African Republic, Chile, China, China (Hong Kong), China (Macao), Colombia, Congo, Costa Rica, Cote d'Ivoire, Croatia, Cyprus, Dominican Republic, Ecuador, Egypt, El Salvador, Eritrea, Ethiopia, Fiji, Gabon, Gambia, Ghana, Guatemala, Honduras, Hungary, India, Indonesia, Iran, Ireland, Israel, Jamaica, Jordan, Kenya, Korea, Latvia, Lesotho, Madagascar, Malawi, Malaysia, Malta, Mauritius, Mexico, Mongolia, Morocco, Namibia, Nepal, Nicaragua, Niger, Nigeria, Oman, Pakistan, Panama, 
Papua New Guinea, Paraguay, Peru, Philippines, Poland, Portugal, Romania, Russian Federation, Rwanda, Senegal, Sierra Leone, Singapore, Slovakia, Slovenia, South Africa, Spain, Sri Lanka, Swaziland, Syrian Arab Republic, Tanzania, Thailand, Togo, Tonga, Trinidad and Tobago, Tunisia, Turkey, Uganda, Uruguay, Venezuela, Zambia, Zimbabwe 
Table 1: Descriptive statistics of the main variables used in regressions

\begin{tabular}{l|cccccc}
\hline \hline \multicolumn{1}{c|}{ Variables } & Obs & Groups & Mean & Stand dev & Min & Max \\
\hline $\begin{array}{l}\text { Labor share (LS) } \\
\text { Foreign Direct Investment stock }\end{array}$ & 1203 & 98 & 33.69 & 14.19 & 2.23 & 85.33 \\
$\quad$ FDI/GDP (FDI/Y, UNCTAD) & 1203 & 98 & 21.27 & 34.69 & 0 & 283.608 \\
Model variables & & & & & \\
$\quad$ Technological gap (TG) & 1203 & 98 & 78.45 & 17.43 & 17.82 & 98.50 \\
(FDI/GDP)*TG (UNCTAD) & 1203 & 98 & 1397.58 & 1771.02 & 0 & 14966.42 \\
Unemployment rate (UNR) & 659 & 70 & 9.19 & 6.01 & 0.7 & 42.2 \\
$\quad$ Investment output ratio (I/Y) & 871 & 80 & 0.28 & 0.44 & -0.174 & 5.23 \\
\hline \hline For sources and/or calculations see Appendix
\end{tabular}

For sources and/or calculations see Appendix.

\begin{tabular}{|c|c|c|c|c|c|c|}
\hline Variable & & Mean & Stand dev & Min & Max & Obs \\
\hline \multirow[t]{3}{*}{$\overline{\mathrm{LS}}$} & Overall & 33.69 & 14.19 & 2.23 & 85.33 & $\mathrm{~N}=1203$ \\
\hline & Between & & 12.55 & 12.99 & 71.03 & $\mathrm{n}=98$ \\
\hline & Within & & 7.12 & 3.63 & 83.90 & $\mathrm{~T}=12.27$ \\
\hline \multirow[t]{3}{*}{ FDI/GDP (FDI/Y, UNCTAD) } & Overall & 21.27 & 34.69 & 0.0000261 & 283.60 & $N=1203$ \\
\hline & Between & & 25.92 & 0.14 & 165.75 & $\mathrm{n}=98$ \\
\hline & Within & & 18.48 & -68.07 & 193.71 & $\mathrm{~T}=12.27$ \\
\hline
\end{tabular}

For sources and/or calculations see Appendix. 
Table 2: Fixed effects regressions

\begin{tabular}{|c|c|c|c|c|c|c|}
\hline & (a) & (b) & (c) & (d) & (e) & (f) \\
\hline$\overline{F D I / Y}$ & $\begin{array}{c}-0.219^{\star * *} \\
(0.036)\end{array}$ & $\begin{array}{c}-0.121^{\star \star \star} \\
(0.042)\end{array}$ & $\begin{array}{c}-0.226^{\star * \star} \\
(0.034)\end{array}$ & $\begin{array}{c}-0.254^{\star \star \star} \\
(0.052)\end{array}$ & $\begin{array}{l}-0.040 \\
(0.071)\end{array}$ & $\begin{array}{c}0.065 \\
(0.090)\end{array}$ \\
\hline$(\mathrm{FDI} / \mathrm{Y})^{2}$ & $\begin{array}{c}0.00076^{* * *} \\
(0.00012)\end{array}$ & $\begin{array}{c}0.00040^{* * *} \\
(0.00013)\end{array}$ & $\begin{array}{c}0.00065^{\star * *} \\
(0.00010)\end{array}$ & $\begin{array}{c}0.00070^{* * *} \\
(0.00014)\end{array}$ & $\begin{array}{c}0.00000 \\
(0.00024)\end{array}$ & $\begin{array}{l}-0.00027 \\
(0.00029)\end{array}$ \\
\hline $\mathrm{FDI} / \mathrm{Y}^{*} \mathrm{TG}$ & & & & & $\begin{array}{c}-0.0029^{* *} \\
(0.0011)\end{array}$ & $\begin{array}{c}-0.0059^{* * *} \\
(0.0017)\end{array}$ \\
\hline$(\mathrm{FDI} / \mathrm{Y})^{2 \star} \mathrm{TG}$ & & & & & $\begin{array}{l}0.000011^{* *} \\
(4.45 \mathrm{e}-06)\end{array}$ & $\begin{array}{c}0.000017^{\star \star *} \\
(5.85 \mathrm{e}-06)\end{array}$ \\
\hline TG & $\begin{array}{l}-0.086 \\
(0.070)\end{array}$ & $\begin{array}{c}-0.156^{\star *} \\
(0.065)\end{array}$ & $\begin{array}{c}-0.319^{* * *} \\
(0.075)\end{array}$ & $\begin{array}{c}-0.187^{* *} \\
(0.085)\end{array}$ & $\begin{array}{l}-0.225^{\star *} \\
(0.090)\end{array}$ & $\begin{array}{c}0.063 \\
(0.113)\end{array}$ \\
\hline $\mathrm{I} / \mathrm{Y}$ & & & $\begin{array}{c}0.743 \\
(0.610)\end{array}$ & $\begin{array}{l}4.512^{*} \\
(2.515)\end{array}$ & $\begin{array}{c}0.763 \\
(0.613)\end{array}$ & $\begin{array}{l}4.550^{*} \\
(2.503)\end{array}$ \\
\hline UNR & & & & $\begin{array}{c}-0.671^{\star \star *} \\
(0.167)\end{array}$ & & $\begin{array}{c}-0.809^{\star * *} \\
(0.183)\end{array}$ \\
\hline Fixed effects & yes & yes & yes & yes & yes & yes \\
\hline Time dummies & no & yes & yes & yes & yes & yes \\
\hline R-squared & 0.045 & 0.154 & 0.230 & 0.280 & 0.235 & 0.297 \\
\hline No observations & 1203 & 1137 & 794 & 460 & 794 & 460 \\
\hline No countries & 98 & 96 & 76 & 55 & 76 & 55 \\
\hline
\end{tabular}

Robust standard errors in brackets. ${ }^{*}$ significant at $10 \%$; ${ }^{* *}$ significant at $5 \%$; ${ }^{* * *}$ significant at $1 \%$. In regressions $\mathrm{b}$ to $\mathrm{f}$, all regressors are one-period lagged. 
Table 3: Omitted variables

\begin{tabular}{|c|c|c|c|c|c|c|c|}
\hline & (a) & (b) & (c) & (d) & (e) & (f) & (g) \\
\hline$\overline{F D I} / Y$ & $\begin{array}{c}-0.226^{\star \star \star} \\
(0.034)\end{array}$ & $\begin{array}{c}-0.222^{* * *} \\
(0.056)\end{array}$ & $\begin{array}{c}-0.385^{\star * *} \\
(0.062)\end{array}$ & $\begin{array}{c}-0.349^{\star * \star} \\
(0.060)\end{array}$ & $\begin{array}{c}-0.396^{\star * *} \\
(0.062)\end{array}$ & $\begin{array}{c}-0.413^{\star \star \star} \\
(0.080)\end{array}$ & $\begin{array}{c}-0.439^{\star \star \star} \\
(0.083)\end{array}$ \\
\hline$(\mathrm{FDI} / \mathrm{Y})^{2}$ & $\begin{array}{c}0.00065^{* * *} \\
(0.00010)\end{array}$ & $\begin{array}{l}0.00064^{* * *} \\
(0.00015)\end{array}$ & $\begin{array}{l}0.0010^{* * *} \\
(0.00017)\end{array}$ & $\begin{array}{c}0.00097^{* * *} \\
(0.00016)\end{array}$ & $\begin{array}{l}0.0010^{* * *} \\
(0.00016)\end{array}$ & $\begin{array}{l}0.0011^{* * *} \\
(0.00020)\end{array}$ & $\begin{array}{l}0.0011^{* * *} \\
(0.00021)\end{array}$ \\
\hline $\mathrm{TG}$ & $\begin{array}{c}-0.319^{* * *} \\
(0.075)\end{array}$ & $\begin{array}{c}-0.353^{* * *} \\
(0.104)\end{array}$ & $\begin{array}{c}-0.328^{* * *} \\
(0.098)\end{array}$ & $\begin{array}{l}-0.202^{*} \\
(0.104)\end{array}$ & $\begin{array}{l}-0.140 \\
(0.112)\end{array}$ & $\begin{array}{c}-0.644^{\star * *} \\
(0.193)\end{array}$ & $\begin{array}{c}-0.531^{* * *} \\
(0.137)\end{array}$ \\
\hline $\mathrm{I} / \mathrm{Y}$ & $\begin{array}{c}0.743 \\
(0.610)\end{array}$ & $\begin{array}{l}1.278^{*} \\
(0.703)\end{array}$ & $\begin{array}{c}0.298 \\
(0.614)\end{array}$ & $\begin{array}{l}-0.543 \\
(0.639)\end{array}$ & $\begin{array}{c}0.561 \\
(0.923)\end{array}$ & $\begin{array}{l}9.045^{\star *} \\
(4.056)\end{array}$ & $\begin{array}{l}7.961^{*} \\
(4.198)\end{array}$ \\
\hline OPENK & & $\begin{array}{l}1.600^{\star \star * *} \\
(0.579)\end{array}$ & $\begin{array}{c}0.565 \\
(0.470)\end{array}$ & $\begin{array}{c}0.395 \\
(0.461)\end{array}$ & $\begin{array}{c}0.175 \\
(0.480)\end{array}$ & $\begin{array}{l}-0.054 \\
(0.637)\end{array}$ & \\
\hline OPENT & & $\begin{array}{l}-0.016 \\
(0.023)\end{array}$ & $\begin{array}{c}0.023 \\
(0.027)\end{array}$ & $\begin{array}{l}0.0095 \\
(0.026)\end{array}$ & $\begin{array}{l}0.0023 \\
(0.028)\end{array}$ & $\begin{array}{c}0.061 \\
(0.041)\end{array}$ & \\
\hline CRISIS & & $\begin{array}{c}-2.515^{\star * *} \\
(0.948)\end{array}$ & $\begin{array}{c}-1.830^{* *} \\
(0.813)\end{array}$ & $\begin{array}{c}-1.966^{* *} \\
(0.771)\end{array}$ & $\begin{array}{c}-1.837^{* *} \\
(0.784)\end{array}$ & $\begin{array}{l}-1.220 \\
(0.996)\end{array}$ & \\
\hline FDI/Y (Outward) & & $\begin{array}{c}0.00055 \\
(0.022)\end{array}$ & $\begin{array}{l}0.308^{*} \\
(0.176)\end{array}$ & $\begin{array}{c}0.520^{\star \star \star *} \\
(0.181)\end{array}$ & $\begin{array}{l}0.325^{*} \\
(0.185)\end{array}$ & $\begin{array}{l}-0.221 \\
(0.337)\end{array}$ & \\
\hline REG & & & $\begin{array}{c}-4.022^{\star * *} \\
(1.025)\end{array}$ & $\begin{array}{c}-4.214^{\star \star \star} \\
(1.002)\end{array}$ & $\begin{array}{c}-5.132^{\star * *} \\
(1.012)\end{array}$ & $\begin{array}{c}-5.785^{\star * *} \\
(1.347)\end{array}$ & \\
\hline SoG & & & $\begin{array}{c}-2.346^{\star * *} \\
(0.809)\end{array}$ & $\begin{array}{c}-2.534^{\star * *} \\
(0.772)\end{array}$ & $\begin{array}{c}-3.024^{* * *} \\
(0.816)\end{array}$ & $\begin{array}{l}-1.225 \\
(1.321)\end{array}$ & \\
\hline DEMO & & & & $\begin{array}{c}-5.729^{* \star *} \\
(1.068)\end{array}$ & $\begin{array}{c}-6.159^{* * *} \\
(1.160)\end{array}$ & $\begin{array}{c}-4.518^{\star * *} \\
(1.359)\end{array}$ & \\
\hline EDU & & & & & $\begin{array}{c}1.416 \\
(0.896)\end{array}$ & $\begin{array}{c}-4.447^{* * *} \\
(1.562)\end{array}$ & \\
\hline UNR & & & & & & $\begin{array}{l}-0.338^{*} \\
(0.200)\end{array}$ & \\
\hline Fixed effects & yes & yes & yes & yes & yes & yes & yes \\
\hline Time dummies & yes & yes & yes & yes & yes & yes & yes \\
\hline R-squared & 0.230 & 0.273 & 0.342 & 0.374 & 0.383 & 0.469 & 0.333 \\
\hline No observations & 794 & 624 & 552 & 552 & 499 & 311 & 311 \\
\hline No countries & 76 & 61 & 57 & 57 & 50 & 39 & 39 \\
\hline
\end{tabular}

Robust standard errors in brackets. ${ }^{*}$ significant at $10 \% ;{ }^{* *}$ significant at $5 \% ;{ }^{* * *}$ significant at $1 \%$. All regressors are one-period lagged. 
Table 4: First-stage regressions

\begin{tabular}{|c|c|c|c|c|}
\hline & (a) & (b) & (c) & (d) \\
\hline Dependent variable & FDIY & $\overline{\text { FDIY }^{2}}$ & FDIY & FDIY \\
\hline NOS & $\begin{array}{l}-0.018 \\
(0.015)\end{array}$ & $\begin{array}{l}-2.782 \\
(2.521)\end{array}$ & $\begin{array}{c}-0.031^{* \star *} \\
(0.010)\end{array}$ & $\begin{array}{c}-0.0083 \\
(0.013)\end{array}$ \\
\hline NSNA & $\begin{array}{l}-0.075^{*} \\
(0.038)\end{array}$ & $\begin{array}{l}-3.232 \\
(4.088)\end{array}$ & $\begin{array}{l}0.041^{* * *} \\
(0.0058)\end{array}$ & $\begin{array}{l}0.033^{* * *} \\
(0.0095)\end{array}$ \\
\hline ISFU & $\begin{array}{c}16.61^{* * *} \\
(3.84)\end{array}$ & $\begin{array}{c}242.23 \\
(647.79)\end{array}$ & $\begin{array}{c}16.66^{\star * *} \\
(3.788)\end{array}$ & $\begin{array}{c}16.32^{* * \star} \\
(4.721)\end{array}$ \\
\hline DNAER & $\begin{array}{c}0.315 \\
(0.292)\end{array}$ & $\begin{array}{c}74.64 \\
(63.39)\end{array}$ & $\begin{array}{c}0.278 \\
(0.224)\end{array}$ & $\begin{array}{c}0.586 \\
(0.460)\end{array}$ \\
\hline $\mathrm{NOS}^{2}$ & $\begin{array}{l}-0.000064^{*} \\
(0.000035)\end{array}$ & $\begin{array}{c}-0.00006 \\
(0.0073)\end{array}$ & & \\
\hline NSNA $^{2}$ & $\begin{array}{l}0.00024^{\star * *} \\
(0.000078)\end{array}$ & $\begin{array}{c}0.012 \\
(0.0085)\end{array}$ & & \\
\hline DNAER ${ }^{2}$ & $\begin{array}{l}-0.00061 \\
(0.0034)\end{array}$ & $\begin{array}{c}0.814 \\
(0.592)\end{array}$ & & \\
\hline TG & $\begin{array}{c}0.081 \\
(0.212)\end{array}$ & $\begin{array}{c}91.00 \\
(60.09)\end{array}$ & $\begin{array}{c}0.081 \\
(0.019)\end{array}$ & $\begin{array}{c}0.262 \\
(0.236)\end{array}$ \\
\hline IY & $\begin{array}{l}-0.407 \\
(0.628)\end{array}$ & $\begin{array}{c}23.97 \\
(132.57)\end{array}$ & $\begin{array}{l}-0.380 \\
(0.619)\end{array}$ & $\begin{array}{c}2.852 \\
(2.125)\end{array}$ \\
\hline UNR & & & & $\begin{array}{c}-0.569^{\star *} \\
(0.276)\end{array}$ \\
\hline Fixed effects & yes & yes & yes & yes \\
\hline Time dummies & yes & yes & yes & yes \\
\hline R-squared & 0.171 & 0.049 & 0.166 & 0.211 \\
\hline No observations & 752 & 752 & 752 & 399 \\
\hline No countries & 75 & 75 & 75 & 50 \\
\hline
\end{tabular}

Robust standard errors in brackets. ${ }^{*}$ significant at 10\%; ** significant at 5\%; *** significant at $1 \%$. 
Table 5: IV regressions (2SLS)

\begin{tabular}{|c|c|c|c|c|c|c|c|c|c|c|}
\hline & (a) & (b) & (c) & (d) & (e) & $(\mathrm{f})$ & (g) & (h) & (i) & (j) \\
\hline Specification & IV & IV & IV & IV & IV & IV & IV & IV & IV & OLS \\
\hline $\mathrm{FDI} / \mathrm{Y}$ & $\begin{array}{c}-0.634^{\star \star *} \\
(0.119)\end{array}$ & $\begin{array}{c}-0.587^{\star \star \star} \\
(0.107)\end{array}$ & $\begin{array}{c}-0.586^{\star * *} \\
(0.095)\end{array}$ & $\begin{array}{c}-0.496^{\star \star *} \\
(0.129)\end{array}$ & $\begin{array}{c}-0.599^{\star * *} \\
(0.104)\end{array}$ & $\begin{array}{c}-0.608^{* * *} \\
(0.125)\end{array}$ & $\begin{array}{c}-0.626^{* * *} \\
(0.096)\end{array}$ & $\begin{array}{c}-0.637^{\star \star *} \\
(0.117)\end{array}$ & $\begin{array}{c}-0.638^{* * *} \\
(0.112)\end{array}$ & $\begin{array}{l}-0.249^{* * *} \\
(0.00069)\end{array}$ \\
\hline $\mathrm{FDI} / \mathrm{Y}^{2}$ & $\begin{array}{l}0.00054 \\
(0.0011)\end{array}$ & $\begin{array}{l}0.000088 \\
(0.00099)\end{array}$ & & & & & & & & $\begin{array}{c}0.00069^{* * *} \\
(0.00018)\end{array}$ \\
\hline TG & $\begin{array}{c}-0.336^{\star * *} \\
(0.098)\end{array}$ & $\begin{array}{c}-0.335^{\star *} \\
(0.141)\end{array}$ & $\begin{array}{c}-0.292^{\star *} \\
(0.139)\end{array}$ & $\begin{array}{c}-0.301^{* *} \\
(0.122)\end{array}$ & $\begin{array}{c}-0.291^{\star *} \\
(0.140)\end{array}$ & $\begin{array}{l}-0.273^{*} \\
(0.141)\end{array}$ & $\begin{array}{c}-0.433^{* * *} \\
(0.152)\end{array}$ & $\begin{array}{l}-0.313^{*} \\
(0.185)\end{array}$ & $\begin{array}{c}-0.440^{* * *} \\
(0.155)\end{array}$ & $\begin{array}{c}-0.388^{\star * *} \\
(0.082)\end{array}$ \\
\hline $\mathrm{I} / \mathrm{Y}$ & $\begin{array}{c}2.457^{* * *} \\
(0.549)\end{array}$ & $\begin{array}{l}8.367^{* *} \\
(3.409)\end{array}$ & $\begin{array}{c}2.514^{\star * *} \\
(0.609)\end{array}$ & $\begin{array}{c}2.245^{\star * *} \\
(0.595)\end{array}$ & $\begin{array}{c}2.509^{* * *} \\
(0.614)\end{array}$ & $\begin{array}{c}2.198^{\star * *} \\
(0.598)\end{array}$ & $\begin{array}{l}1.624^{* *} \\
(0.666)\end{array}$ & $\begin{array}{l}8.457^{* *} \\
(3.634)\end{array}$ & $\begin{array}{l}9.220^{* *} \\
(3.626)\end{array}$ & $\begin{array}{c}2.580^{* * *} \\
(0.529)\end{array}$ \\
\hline UNR & & $\begin{array}{c}-0.471^{\star *} \\
(0.188)\end{array}$ & & & & & & $\begin{array}{c}-0.504^{\star *} \\
(0.200)\end{array}$ & & \\
\hline Fixed effects & yes & yes & yes & yes & yes & yes & yes & yes & yes & \\
\hline Time dummies & yes & yes & yes & yes & yes & yes & yes & yes & yes & \\
\hline No observations & 752 & 434 & 752 & 752 & 752 & 759 & 797 & 435 & 435 & 752 \\
\hline No countries & 66 & 45 & 66 & 66 & 66 & 66 & 67 & 45 & 45 & 66 \\
\hline Hansen overidentification test & 0.21 & 0.46 & 0.69 & 0.93 & 0.52 & 0.57 & 0.82 & 0.93 & 0.96 & $\cdot$ \\
\hline KP test (underidentification) & 0.46 & 0.35 & 0.00 & 0.00 & 0.00 & 0.00 & 0.00 & 0.00 & 0.00 & . \\
\hline F test statistics (FDIY) & 15.68 & 7.91 & 20.54 & 18.94 & 25.90 & 11.49 & 22.48 & 9.78 & 10.30 & . \\
\hline F test statistics (FDIY²) & 4.50 & 1.43 & & & & & & & & . \\
\hline KP rk Wald F statistic & 0.68 & 0.79 & 20.54 & 18.94 & 25.90 & 11.49 & 22.48 & 9.78 & 10.30 & . \\
\hline Maximum IV relative bias & $>30 \%$ & $>30 \%$ & $<5 \%$ & $<5 \%$ & $<5 \%$ & $<10 \%$ & $<5 \%$ & $\approx 10 \%$ & $\approx 10 \%$ & 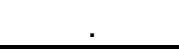 \\
\hline
\end{tabular}

KP is for Kleibergen-Paap. Robust standard errors in brackets. ${ }^{\star}$ significant at $10 \% ;{ }^{* \star}$ significant at $5 \% ;{ }^{* \star \star}$ significant at $1 \%$.

In columns (a), (b), (c), (h) and (i) we use four instruments: number of oppositional seats (NOS), number of seats non aligned

(NSNA), Independent sub-federal units (ISFU) and Decentralization of non-agricultural resources (DNAR) indices.

Column (d) omits the ISFU instrument, column (e) omits NOS, column (f) omits NSNA, and column (g) omits DNAR. 


\title{
Web Appendix to FDI and the labor share in developing countries: A theory and some evidence
}

\author{
Bruno Decreuse* \\ Aix-Marseille University (Aix-Marseille School of Economics), EHESS \& CNRS \\ Paul Maarek \\ University of Cergy-Pontoise
}

March 30, 2013

In this web Appendix, we run the regressions over various alterations of the initial sample: exclusion of city states, exclusion of extreme observations, different samples of developing countries, and samples of developed economies. We also consider several alterations in investment, capital variables and technological gap: aggregate capital stock vs manufacturing investment, ratio of FDI stock to capital stock vs ratio of FDI stock to GDP, and TFP vs GDP per capita. We also consider more carefully the globalization variable previously considered in the literature.

Table A1 considers several alterations in investment and capital variables, i.e. the ratio of FDI stock to GDP and the ratio of investment to GDP. In the paper, we proxy the percentage of jobs in foreign firms by the ratio of (inward) FDI stock to GDP (FDI/Y). We here consider an alternative variable, the ratio of FDI stock to total capital stock (FDI/K). This ratio is computed from UNCTAD data on FDI stock and from Klenow and Rodriguez-Clare [1] for the capital stock. ${ }^{1}$ We also use alternative data on FDI stocks provided by Lane and Milesi-Ferretti [2]. These data are available over the longer period 1970-2005 and allow us to test the robustness of our results.

Column a reproduces our benchmark regression: FDI stock is from UNCTAD and it is divided by GDP. In column b FDI stock is from Lane and Milesi-Ferretti. In column c and d the two FDI stock variables are divided by the total capital stock rather than by GDP. In columns e to $h$ we replace the investment to output ratio in the manufacturing sector by the economywide capital stock to GDP ratio. Results are qualitatively unchanged: all the different parameters have the same sign and significance.

We then run the regressions over various alterations of the initial sample. Table A2 displays the results. They must be compared to Table 2 column c in the paper. We first compute the empirical distribution of percentage change in LS $\left(\Delta \mathrm{LS}_{i t} / \mathrm{LS}_{i t}\right)$. We then omit the observations belonging to the top 1 and top 2 percentile of this distribution and run fixed effects regressions. The results are reported in columns

\footnotetext{
${ }^{*}$ Corresponding author. GREQAM 2, rue de la charité 13236 Marseille cedex 2, France. Phone number: +33 (0)4 9114 07 22. Fax number: +33 (0) 4911407 27. E-mail: bruno.decreuse@univ-amu.fr

${ }^{1}$ Initial values for the capital stock and the FDI stock have not been computed in the same way. This explains why the ratio $\mathrm{FDI} / \mathrm{K}$ can be larger than one.
} 
$\mathrm{a}$ and b. The magnitude of the relationship between FDI/Y and LS is almost unchanged. Columns c and $d$ omit observations where the FDI stock to GDP is larger than $100 \%$ and $75 \%$ respectively. As expected, the negative coefficient associated to FDI/Y is much stronger, whereas the positive coefficient associated to $(\mathrm{FDI} / \mathrm{Y})^{2}$ is less significant. In column e, we use an alternative measure for the technological gap. Instead of using GDP per worker, we use the measure of TFP due to Klenow (2005). Results are qualitatively unchanged. Column $\mathrm{f}$ drops the three city states from the sample namely, Hong Kong, Macao and Singapore. The results are close to the initial estimates.

Table A3 considers different thresholds of Technological Gap to define the set of developing countries. It also runs the regressions on different samples of developed countries. Column a corresponds to our baseline regression of Table 2 column c. The sample of developing countries is restricted to countries whose GDP per capita was lower than $60 \%$ that of the US in 1980. In columns b-f, we use more restrictive thresholds, from $50 \%$ to $30 \%$. The number of countries decreases accordingly. When the threshold is $50 \%$, the results are almost unchanged. When the threshold becomes smaller, the ratio FDI/Y falls. As a result the relationship is mainly negative and including FDI/Y ${ }^{2}$ creates a mispecification: in column $\mathrm{c}$ both FDI/Y and FDI/ $\mathrm{Y}^{2}$ are negative (and unsignificant). As a result, in column $\mathrm{d}$ and $\mathrm{f}$ we estimate the relationship without FDI $/ \mathrm{Y}^{2}$. The coefficients for FDI/Y are negative and significant. Column $\mathrm{g}$ to $\mathrm{l}$ correspond to regressions on samples of developed countries. Column $\mathrm{g}$ and $\mathrm{h}$ correspond to the initial members of OECD only, column i and j correspond to countries whose GDP per capita is higher than $60 \%$ that of the US in 1980 and column $\mathrm{k}$ and $\mathrm{l}$ correspond to countries whose GDP per capita is higher than $50 \%$ that of the US in 1980. For OCDE countries, the relationship seems to be weakly positive. For developed countries whose GDP per capita is higher than 60\% that of the US in 1980 the relationship is non significant. For developed economies whose GDP per capita is higher than $50 \%$ that of the US in 1980 (thus a less restrictive sample than the previous one), the relationship is weakly negative but with a magnitude seven times lower than our baseline estimates.

Overall Table A3 confirms that the different effects of our model are very robust in developing countries. FDI variables, in particular, are strongly significant. Converseley, FDI variables have no effects or very small effects in developed economies. These results are in line with the theory.

Table A4 highlights the role of other globalization measures previously emphasized by the literature. We run the regressions of Table 3, but we exclude FDI/Y and FDI/Y ${ }^{2}$. Column a considers only two control variables TG and I/Y. The impact of TG remains the same. Column b consider the inclusion of OPENT, OPENK and CRISIS. OPENT and CRISIS have a negative impact on the labor share in line with previous findings. OPENK, which corresponds to de jure financial openness, has no impact. Column c uses the same sample as Table 3. This sample is smaller than the previous columns because the consideration of FDI variables leads to lose about 150 observations. Column d includes outward FDI stock. The impact of trade remains negative but unsignificant. CRISIS still has a negative and significant impact. Capital account openness now has a positive and significant impact. In column e, we include the other institutionnal controls and education and we lose 150 observations again. Only CRISIS remains significant.

Table A4 shows that, unlike FDI variables, the impact of globalization variables is very sensitive to sample alterations. However, the comparison with previous studies is difficult due to the fact our paper 
only focuses on developing economies, whereas previous papers also considered developed economies, and such countries were overrepresented in their samples. Moreover, we focus on the manufacturing sector labor share, whereas these other studies are interested in the aggregate labor share.

\section{References}

[1] P.J. Klenow, A. Rodriguez-Clare, Externalities and growth, in: P. Aghion, S. Durlauf (Eds), Handbook of Economic Growth vol. 1A, Chapter 11, Elsevier, 2005, pp. 817-861.

[2] P.R. Lane, G.M. Milesi-Ferretti, The external wealth of nations mark II: revised and extended estimates of foreign assets and liabilities, J Int Econ 73 (2007) 223-250. 
List of variables

- CRISIS: Exchange rate crisis. Dummy equal to one if the percentage increase in nominal exchange rate is larger than $25 \%$. The exchange rate is measured at the end of the year.

Source: IMF

- DEMO: Type of regime. Coded 0 if democracy; 1 if dictatorship

Source: Cheibub and Gandhi (2004)

- DNAR: Decentralization of non-agricultural ressources. each country's economic system was categorized as being centrally planned, public sector dominated, market oriented with concentrated ownership, or market oriented with diversified ownership; then the degree of concentration of ownership within each category was determined.

Source: Vanhanen (2003)

- EDU: Average schooling years in the total population aged 25 and over.

Source: Barro and Lee (2000)

- FDI/Y = Ratio of Foreign Direct Investment stock to GDP

Source: UNCTAD and Lane and Milesi-Ferretti (2007) for FDI

Data available at http://www.imf.org/external/pubs/ft/wp/2006/data/wp0669.zip

- FDI/K = Ratio of Foreign Direct Investment stock to total capital stock

Source: UNCTAD and Lane and Milesi-Ferretti (2007) for FDI

Data available at http://www.imf.org/external/pubs/ft/wp/2006/data/wp0669.zip

Source: Klenow and Rodriguez-Clare (2005) for the capital stock

- $\mathrm{I} / \mathrm{Y}=$ Ratio of Investment to value-added in the manufacturing sector

Source: UNIDO industrial statistics database INDSTAT3 2005 ISIC Rev.2

Values lower than 0 have been omitted from the sample

- ISFU: Independent Sub-Federal Units. Coded 0 if no ISFU; 1 if ISFU

Source: The Political Constraints Index, Henisz (2004)

- $\mathrm{K} / \mathrm{Y}=$ Ratio of total capital stock to total GDP

Source: Klenow and Rodriguez-Clare (2005)

- LS: Labor share $=$ Ratio of wages and salaries to value added $(\times 100)$

Source: UNIDO industrial statistics database INDSTAT3 2005 ISIC Rev.2

- NOS: Number of Oppositional Seats

Source: Database of Political Institutions (2005). World Bank 
- NSNA: Number of Seats non-aligned/allegiance unknown

Source: Database of Political Institutions (2005). World Bank

- OPENK: Chinn and Ito financial openness index. Composite index varying between 2.62 (very open) and -1.75 (close). It is based on four dummy variables reflecting the four major categories on the restrictions on external accounts: presence of multiple exchange rates, restrictions on current account transactions, restrictions on capital account transactions, requirement of the surrender of export proceed.

Source: Chinn and Ito (2007)

Data available at http://www.ssc.wisc.edu/ ${ }^{\sim}$ mchinn/kaopen_2006.xls

- $\mathrm{OPENT}=$ Ratio of total exports and imports to GDP

Source: World bank. World Development Indicators 2005

- REG: 10 minus the Regulation of Credit, Labor and Business. The index ranges from 0 to 10 where 0 corresponds to low regulation and 10 corresponds to high regulation.

Source: Fraser Institute

- SoG: Size of Government: Expenditures, Taxes, and Enterprises. The index ranges from 0-10 where 0 corresponds to large government and 10 to low government.

Source: Fraser Institute

- TG: Technological gap = One - percentage gap between local GDP (PPP) per capita and US GDP per capita $(\times 100)$

Source: World bank. World Development Indicators 2005

- UNR: Unemployment rate $=$ Ratio of unemployed workers to total labor force

Source: World bank. World Development Indicators 2005 
Table A1: Changes in FDI variable and capital stock variable

\begin{tabular}{|c|c|c|c|c|c|c|c|c|}
\hline Data & $\begin{array}{c}\text { (a) } \\
\text { UNCTAD }\end{array}$ & $\begin{array}{c}\text { (b) } \\
\text { LMF }\end{array}$ & $\begin{array}{c}(\mathrm{c}) \\
\text { UNCTAD }\end{array}$ & $\begin{array}{c}\text { (d) } \\
\text { LMF }\end{array}$ & $\begin{array}{c}(\mathrm{e}) \\
\text { UNCTAD }\end{array}$ & $\begin{array}{c}(\mathrm{f}) \\
\text { LMF }\end{array}$ & $\begin{array}{c}(\mathrm{g}) \\
\text { UNCTAD }\end{array}$ & $\begin{array}{c}\text { (h) } \\
\text { LMF }\end{array}$ \\
\hline $\mathrm{FDI} / \mathrm{Y}$ & $\begin{array}{c}-0.226^{\star * \star} \\
(0.034)\end{array}$ & $\begin{array}{c}-0.218^{\star \star \star} \\
(0.039)\end{array}$ & & & $\begin{array}{c}-0.142^{\star *} \\
(0.066)\end{array}$ & $\begin{array}{c}-0.122^{\star \star} \\
(0.050)\end{array}$ & & \\
\hline$(\mathrm{FDI} / \mathrm{Y})^{2}$ & $\begin{array}{c}0.00065^{\star * *} \\
(0.00010)\end{array}$ & $\begin{array}{c}0.00058^{* * *} \\
(0.00011)\end{array}$ & & & $\begin{array}{c}0.00050^{* * *} \\
(0.00018)\end{array}$ & $\begin{array}{l}0.00030^{* *} \\
(0.00015)\end{array}$ & & \\
\hline $\mathrm{FDI} / \mathrm{K}$ & & & $\begin{array}{c}-0.489^{* * *} \\
(0.070)\end{array}$ & $\begin{array}{c}-0.388^{* * *} \\
(0.066)\end{array}$ & & & $\begin{array}{c}-0.264^{\star * *} \\
(0.086)\end{array}$ & $\begin{array}{c}-0.222^{* \star *} \\
(0.070)\end{array}$ \\
\hline$(\mathrm{FDI} / \mathrm{K})^{2}$ & & & $\begin{array}{l}0.0021^{* * *} \\
(0.00028)\end{array}$ & $\begin{array}{l}0.0016^{* * *} \\
(0.00041)\end{array}$ & & & $\begin{array}{l}0.0014^{* * *} \\
(0.00035)\end{array}$ & $\begin{array}{c}0.00059 \\
(0.00048)\end{array}$ \\
\hline TG & $\begin{array}{c}-0.319^{\star * *} \\
(0.075)\end{array}$ & $\begin{array}{c}-0.402^{* * *} \\
(0.066)\end{array}$ & $\begin{array}{c}-0.366^{\star \star \star} \\
(0.089)\end{array}$ & $\begin{array}{c}-0.404^{\star \star \star} \\
(0.078)\end{array}$ & $\begin{array}{c}-0.215^{\star \star \star} \\
(0.078)\end{array}$ & $\begin{array}{l}-0.135^{\star} \\
(0.076)\end{array}$ & $\begin{array}{c}-0.221^{\star \star \star} \\
(0.075)\end{array}$ & $\begin{array}{l}-0.160^{\star *} \\
(0.073)\end{array}$ \\
\hline $\mathrm{I} / \mathrm{Y}$ & $\begin{array}{c}0.743 \\
(0.610)\end{array}$ & $\begin{array}{c}0.772 \\
(0.584)\end{array}$ & $\begin{array}{c}1.202 \\
(0.732)\end{array}$ & $\begin{array}{c}0.894 \\
(0.635)\end{array}$ & & & & \\
\hline $\mathrm{K} / \mathrm{Y}$ & & & & & $\begin{array}{l}2.877^{*} \\
(1.495)\end{array}$ & $\begin{array}{l}1.891^{*} \\
(1.137)\end{array}$ & $\begin{array}{c}2.144 \\
(1.502)\end{array}$ & $\begin{array}{c}1.026 \\
(1.135)\end{array}$ \\
\hline Fixed effects & yes & yes & yes & yes & yes & yes & yes & yes \\
\hline Time dummies & yes & yes & yes & yes & yes & yes & yes & yes \\
\hline R-squared & 0.230 & 0.201 & 0.260 & 0.209 & 0.159 & 0.135 & 0.172 & 0.153 \\
\hline No observations & 794 & 880 & 639 & 743 & 903 & 1086 & 901 & 1084 \\
\hline No countries & 76 & 69 & 59 & 55 & 69 & 66 & 69 & 66 \\
\hline
\end{tabular}

Robust standard errors in brackets. ${ }^{*}$ significant at 10\%; ${ }^{* \star}$ significant at 5\%; ${ }^{\star \star \star}$ significant at $1 \%$.

All regressors are one-period lagged. 
Table A2: In search for outliers

\begin{tabular}{|c|c|c|c|c|c|c|}
\hline Specification & $\begin{array}{c}(\mathrm{a}) \\
99 \% \\
\end{array}$ & $\begin{array}{c}(b) \\
98 \% \\
\end{array}$ & $\begin{array}{c}(c) \\
F D I / Y<100\end{array}$ & $\begin{array}{c}\text { (d) } \\
\text { FDI } / Y<75\end{array}$ & $\begin{array}{c}(\mathrm{e}) \\
\mathrm{TG} \text { TFP }\end{array}$ & $\begin{array}{c}\mathrm{f}) \\
\text { w/o city states }\end{array}$ \\
\hline$\overline{\mathrm{FDI} / Y}$ & $\begin{array}{c}-0.224^{* * *} \\
(0.033)\end{array}$ & $\begin{array}{c}-0.217^{\star \star \star} \\
(0.033)\end{array}$ & $\begin{array}{c}-0.361^{* * *} \\
(0.088)\end{array}$ & $\begin{array}{c}-0.306^{\star * \star} \\
(0.098)\end{array}$ & $\begin{array}{c}-0.235^{\star * \star} \\
(0.054)\end{array}$ & $\begin{array}{c}-0.291^{\star \star \star} \\
(0.051)\end{array}$ \\
\hline$(\mathrm{FDI} / \mathrm{Y})^{2}$ & $\begin{array}{l}0.00064^{\star * *} \\
(0.00010)\end{array}$ & $\begin{array}{c}0.00061^{\star \star *} \\
(0.00010)\end{array}$ & $\begin{array}{c}0.0020^{\star *} \\
(0.00092)\end{array}$ & $\begin{array}{c}0.0010 \\
(0.0011)\end{array}$ & $\begin{array}{c}0.00070^{* * *} \\
(0.00014)\end{array}$ & $\begin{array}{l}0.00081^{* * *} \\
(0.00013)\end{array}$ \\
\hline $\mathrm{TG}$ & $\begin{array}{c}-0.340^{* * *} \\
(0.074)\end{array}$ & $\begin{array}{c}-0.346^{\star * *} \\
(0.074)\end{array}$ & $\begin{array}{l}-0.325^{\star \star \star} \\
(0.077)\end{array}$ & $\begin{array}{c}-0.361^{* * *} \\
(0.083)\end{array}$ & & $\begin{array}{c}-0.425^{\star * \star} \\
(0.100)\end{array}$ \\
\hline TG_TFP & & & & & $\begin{array}{c}-0.475^{\star * *} \\
(0.088)\end{array}$ & \\
\hline $\mathrm{I} / \mathrm{Y}$ & $\begin{array}{c}0.724 \\
(0.603)\end{array}$ & $\begin{array}{c}0.589 \\
(0.597)\end{array}$ & $\begin{array}{c}0.688 \\
(0.620)\end{array}$ & $\begin{array}{c}0.685 \\
(0.621)\end{array}$ & $\begin{array}{c}0.478 \\
(0.700)\end{array}$ & $\begin{array}{c}0.671 \\
(0.632)\end{array}$ \\
\hline Fixed effects & yes & yes & yes & yes & yes & yes \\
\hline Time dummies & yes & yes & yes & yes & yes & yes \\
\hline R-squared & 0.269 & 0.282 & 0.230 & 0.234 & 0.213 & 0.244 \\
\hline No observations & 781 & 773 & 766 & 753 & 614 & 731 \\
\hline No countries & 75 & 75 & 75 & 75 & 56 & 73 \\
\hline
\end{tabular}

Notes: Robust standard in brackets. ${ }^{*}$ significant at $10 \% ;{ }^{* *}$ significant at $5 \% ;{ }^{* \star *}$ significant at $1 \%$. All regressors are one-period lagged. In columns $a$ and $b$, we compute the distribution of $\%$ change in LS. We then omit the observations corresponding to the top $1 \%$ and top $2 \%$ of the distribution. 
Table A3: Developing and developed countries

\begin{tabular}{|c|c|c|c|c|c|c|c|c|c|c|c|c|}
\hline Specification & $\begin{array}{c}\text { (a) } \\
T G>40\end{array}$ & $\begin{array}{c}\text { (b) } \\
T G>50\end{array}$ & $\begin{array}{c}(\mathrm{c}) \\
\mathrm{TG}>60\end{array}$ & $\begin{array}{c}(\mathrm{d}) \\
T G>60\end{array}$ & $\begin{array}{c}(\mathrm{e}) \\
\mathrm{TG}>70\end{array}$ & $\begin{array}{c}(\mathrm{f}) \\
T G>70\end{array}$ & $\begin{array}{c}\text { (g) } \\
\text { OECD }\end{array}$ & $\begin{array}{c}\text { (h) } \\
\text { OECD }\end{array}$ & $\begin{array}{c}\text { (i) } \\
T G<40\end{array}$ & $\begin{array}{c}(\mathrm{j}) \\
\mathrm{TG}<40\end{array}$ & $\begin{array}{c}(\mathrm{k}) \\
\mathrm{TG}<50\end{array}$ & $\begin{array}{c}(\mathrm{I}) \\
\mathrm{TG}<50\end{array}$ \\
\hline$\overline{\mathrm{FDI} / Y}$ & $\begin{array}{c}-0.226^{* * *} \\
(0.034)\end{array}$ & $\begin{array}{c}-0.273^{* * *} \\
(0.049)\end{array}$ & $\begin{array}{l}-0.153 \\
(0.108)\end{array}$ & $\begin{array}{c}-0.153^{* * *} \\
(0.038)\end{array}$ & $\begin{array}{l}-0.196^{*} \\
(0.118)\end{array}$ & $\begin{array}{c}-0.175^{\star * \star} \\
(0.040)\end{array}$ & $\begin{array}{c}-0.138 \\
(0.094)\end{array}$ & $\begin{array}{c}0.060^{\star * *} \\
(0.015)\end{array}$ & $\begin{array}{c}-0.559 \\
(0.489)\end{array}$ & $\begin{array}{c}-0.027 \\
(0.260)\end{array}$ & $\begin{array}{c}-0.033 \\
(0.080)\end{array}$ & $\begin{array}{c}-0.037^{\star \star \star} \\
(0.009)\end{array}$ \\
\hline$(\mathrm{FDI} / \mathrm{Y})^{2}$ & $\begin{array}{c}0.00065^{\star * *} \\
(0.00010)\end{array}$ & $\begin{array}{c}0.00076^{* * *} \\
(0.00013)\end{array}$ & $\begin{array}{c}-2.00 \mathrm{e}-06 \\
(0.0013)\end{array}$ & & $\begin{array}{l}0.00028 \\
(0.0014)\end{array}$ & & $\begin{array}{l}0.00051^{* *} \\
(0.00023)\end{array}$ & & $\begin{array}{c}0.013 \\
(0.017)\end{array}$ & & $\begin{array}{c}-0.000014 \\
(0.00027)\end{array}$ & \\
\hline TG & $\begin{array}{c}-0.319^{* * *} \\
(0.075)\end{array}$ & $\begin{array}{c}-0.228^{* * *} \\
(0.082)\end{array}$ & $\begin{array}{c}-0.243^{\star * *} \\
(0.088)\end{array}$ & $\begin{array}{c}-0.243^{* * *} \\
(0.086)\end{array}$ & $\begin{array}{c}-0.284^{* * *} \\
(0.105)\end{array}$ & $\begin{array}{c}-0.285^{\star * *} \\
(0.104)\end{array}$ & $\begin{array}{c}-0.471^{* * *} \\
(0.163)\end{array}$ & $\begin{array}{c}-0.440^{* * *} \\
(0.160)\end{array}$ & $\begin{array}{c}-0.282^{*} \\
(0.164)\end{array}$ & $\begin{array}{l}-0.276^{*} \\
(0.167)\end{array}$ & $\begin{array}{c}-0.324^{\star *} \\
(0.134)\end{array}$ & $\begin{array}{c}-0.323^{* * *} \\
(0.124)\end{array}$ \\
\hline $\mathrm{I} / \mathrm{Y}$ & $\begin{array}{c}0.743 \\
(0.610)\end{array}$ & $\begin{array}{c}0.319 \\
(0.579)\end{array}$ & $\begin{array}{c}0.621 \\
(0.544)\end{array}$ & $\begin{array}{c}0.621 \\
(0.543)\end{array}$ & $\begin{array}{c}0.596 \\
(0.577)\end{array}$ & $\begin{array}{c}0.600 \\
(0.576)\end{array}$ & $\begin{array}{l}-1.013 \\
(12.11)\end{array}$ & $\begin{array}{l}-8.047 \\
(11.57)\end{array}$ & $\begin{array}{c}21.89^{\star * *} \\
(5.99)\end{array}$ & $\begin{array}{c}22.15^{\star \star \star} \\
(5.98)\end{array}$ & $\begin{array}{c}27.67^{* \star *} \\
(4.74)\end{array}$ & $\begin{array}{c}27.68^{\star \star *} \\
(4.74)\end{array}$ \\
\hline Fixed effects & yes & yes & yes & yes & yes & yes & yes & yes & yes & yes & yes & yes \\
\hline Time dummies & yes & yes & yes & yes & yes & yes & yes & yes & yes & yes & yes & yes \\
\hline R-squared & 0.230 & 0.265 & 0.235 & 0.235 & 0.240 & 0.240 & 0.229 & 0.216 & 0.336 & 0.328 & 0.294 & 0.294 \\
\hline No observations & 794 & 703 & 614 & 614 & 551 & 551 & 236 & 236 & 257 & 257 & 348 & 348 \\
\hline No countries & 76 & 70 & 63 & 63 & 56 & 56 & 17 & 17 & 19 & 19 & 25 & 25 \\
\hline
\end{tabular}

Notes: Robust standard in brackets. ${ }^{*}$ significant at 10\%; ${ }^{* \star}$ significant at $5 \% ;{ }^{* \star}$ significant at $1 \%$.

All regressors are one-period lagged. 
Table A4: Globalization variables

\begin{tabular}{|c|c|c|c|c|c|}
\hline & (a) & (b) & $\overline{(\mathrm{c})}$ & $\overline{(d)}$ & $\overline{(\mathrm{e})}$ \\
\hline$\overline{\mathrm{TG}}$ & $\begin{array}{c}-0.325^{\star \star \star} \\
(0.081)\end{array}$ & $\begin{array}{c}-0.382^{* \star *} \\
(0.070)\end{array}$ & $\begin{array}{c}-0.402^{\star \star \star} \\
(0.108)\end{array}$ & $\begin{array}{c}-0.397^{\star \star \star} \\
(0.111)\end{array}$ & $\begin{array}{l}-0.130 \\
(0.135)\end{array}$ \\
\hline $\mathrm{I} / \mathrm{Y}$ & $\begin{array}{c}0.792 \\
(0.599)\end{array}$ & $\begin{array}{c}2.067^{* * *} \\
(0.766)\end{array}$ & $\begin{array}{l}1.377^{*} \\
(0.713)\end{array}$ & $\begin{array}{l}1.394^{\prime} \\
(0.725)\end{array}$ & $\begin{array}{c}0.863 \\
(0.960)\end{array}$ \\
\hline OPENK & & $\begin{array}{c}0.750 \\
(0.489)\end{array}$ & $\begin{array}{l}1.602^{* * *} \\
(0.595)\end{array}$ & $\begin{array}{l}1.603^{* * *} \\
(0.596)\end{array}$ & $\begin{array}{c}0.110 \\
(0.552)\end{array}$ \\
\hline OPENT & & $\begin{array}{c}-0.057^{* * *} \\
(0.020)\end{array}$ & $\begin{array}{l}-0.034 \\
(0.023)\end{array}$ & $\begin{array}{l}-0.035 \\
(0.024)\end{array}$ & $\begin{array}{l}-0.048 \\
(0.030)\end{array}$ \\
\hline CRISIS & & $\begin{array}{c}-2.248^{\star * *} \\
(0.883)\end{array}$ & $\begin{array}{c}-2.745^{\star * *} \\
(0.991)\end{array}$ & $\begin{array}{c}-2.743^{\star * *} \\
(0.992)\end{array}$ & $\begin{array}{c}-2.591^{\star \star * *} \\
(0.886)\end{array}$ \\
\hline FDI/Y (Outward) & & & & $\begin{array}{l}0.0046 \\
(0.012)\end{array}$ & $\begin{array}{c}0.165 \\
(0.196)\end{array}$ \\
\hline REG & & & & & $\begin{array}{c}-4.406^{\star * *} \\
(1.153)\end{array}$ \\
\hline SoG & & & & & $\begin{array}{c}-3.320^{\star \star \star} \\
(0.888)\end{array}$ \\
\hline DEMO & & & & & $\begin{array}{c}-6.805^{\star * *} \\
(1.190)\end{array}$ \\
\hline EDU & & & & & $\begin{array}{l}1.846^{\star *} \\
(0.919)\end{array}$ \\
\hline Fixed effects & yes & yes & yes & yes & yes \\
\hline Time dummies & yes & yes & yes & yes & yes \\
\hline R-squared & 0.187 & 0.227 & 0.244 & 0.244 & 0.312 \\
\hline No observations & 795 & 795 & 624 & 624 & 499 \\
\hline No countries & 66 & 66 & 61 & 61 & 50 \\
\hline
\end{tabular}

Robust standard errors in brackets. ${ }^{*}$ significant at $10 \% ;{ }^{* *}$ significant at $5 \%$;

${ }^{* * *}$ significant at $1 \%$. All regressors are one-period lagged. 